Cornell Law Library

Scholarship@Cornell Law: A Digital Repository

Cornell Law Faculty Publications

Faculty Scholarship

$4-2003$

\title{
Mercy by the Numbers: An Empirical Analysis of Clemency and its Structure
}

Michael Heise

Cornell Law School, michael.heise@cornell.edu

Follow this and additional works at: http://scholarship.law.cornell.edu/facpub

Part of the Criminal Law Commons, and the Criminal Procedure Commons

\section{Recommended Citation}

Heise, Michael, "Mercy by the Numbers: An Empirical Analysis of Clemency and its Structure" (2003). Cornell Law Faculty Publications. Paper 732.

http://scholarship.law.cornell.edu/facpub/732

This Article is brought to you for free and open access by the Faculty Scholarship at Scholarship@Cornell Law: A Digital Repository. It has been accepted for inclusion in Cornell Law Faculty Publications by an authorized administrator of Scholarship@Cornell Law: A Digital Repository. For more information, please contact jmp8@cornell.edu. 


\title{
VIRGINIA LAW REVIEW
}

\begin{tabular}{lll}
\hline \hline VOLUME 89 & APRUL 2003 & NUMBER 2 \\
\hline \hline
\end{tabular}

\section{ARTICLES}

\section{MERCY BY THE NUMBERS: AN EMPIRICAL ANALYSIS OF CLEMENCY AND ITS STRUCTURE}

\author{
Michael Heise*
}

\section{TABLE OF CONTENTS}

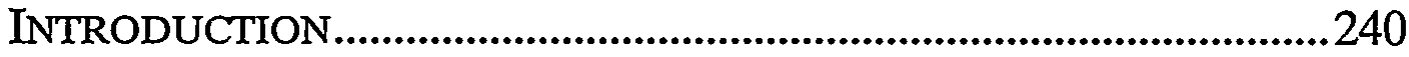

I. DEATH PENALTY AND ClEMENCY........................................245

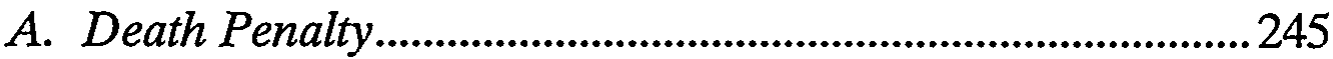

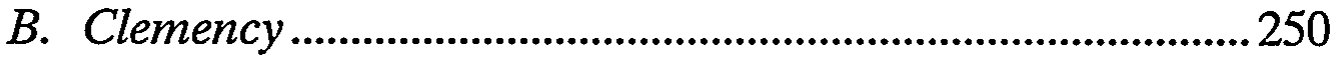

1. Clemency's Unique Role............................................252

2. The Criminal Justice System's Reliance on Clemency. 253

3. The Structure of Clemency Authority............................... 254

II. PREVIOUS STUDIES ...............................................................259

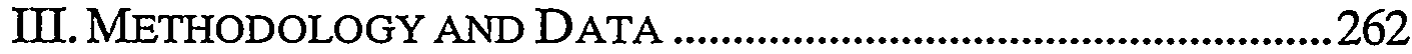

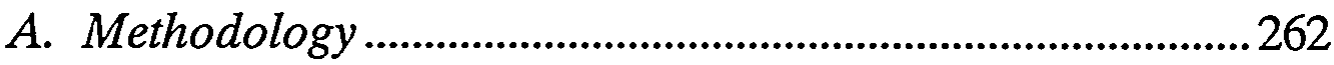

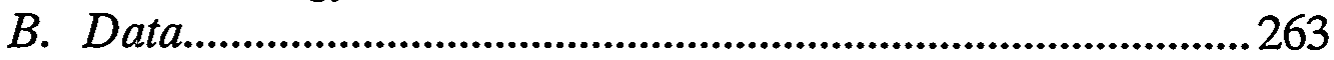

1. Defendant Characteristics...........................................264

2. Political Factors.........................................................265

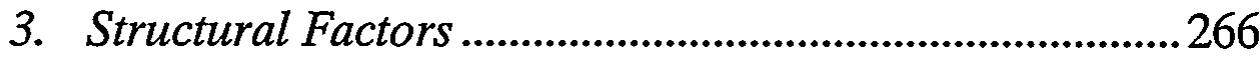

4. Data Limitations.............................................................. 269

* Professor of Law, Case Western Reserve University. A.B., 1983, Stanford University; J.D., 1987, University of Chicago; Ph.D., 1990, Northwestern University. I am grateful to John Blume, Dawn Chutkow, Kevin M. Clermont, Steven Clymer, Dan Cole, Theodore Eisenberg, Stephen Garvey, Sheri L. Johnson, Daniel T. Kobil, Ronald Krotoszynski, Jr., Jonathan Macey, Andy Morriss, Larry Palmer, Elizabeth Rapaport, Steven Shiffrin, Gregory C. Sisk, and Scott Sundby, as well as the participants at faculty workshops at Case Western Reserve, Ohio State, and Cornell law schools. Thanks also to Daniel Fishbein, David Friedman, and the librarians at Case Western Reserve and Cornell universities for excellent research assistance. 


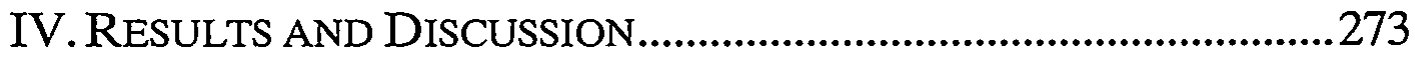

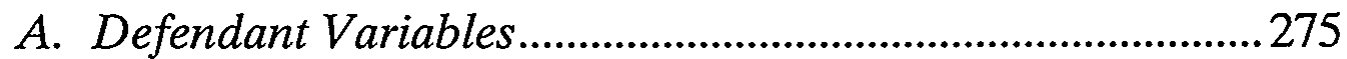

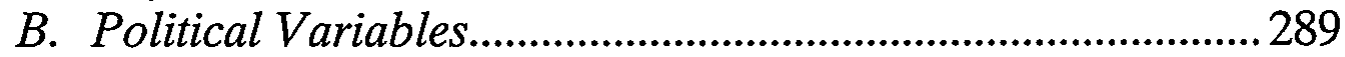

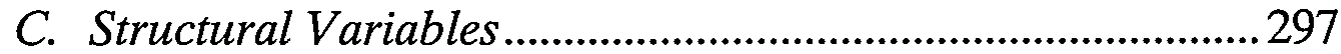

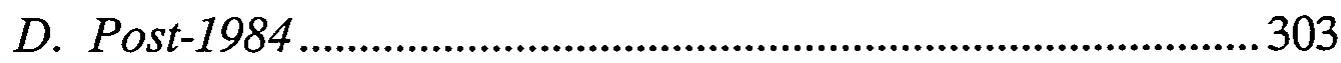

E. Political Factors Influencing Governors ..............................304

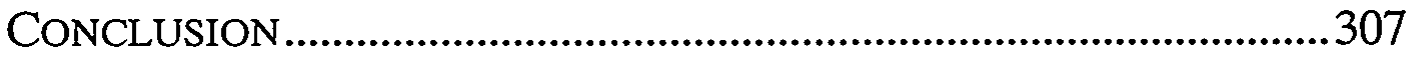

\section{TABLE OF TABLES AND FIGURES}

Figure 1: Imposition of the Death Penalty, 1973-99 ....................249

Figure 2: State Executions, 1977-99 ...................................................250

Figure 3: Clemency Grants, 1973-99 ...........................................251

Table 1: Models of Clemency Authority and Clemency Grants by

Authority ...........................................................................258

Table 2: Descriptive Statistics (Mean and Standard Deviation)..268

Table 3: Death Row Removals Through Clemency ........................274

Table 4: Pure Executive Clemency Decision Model Results ........306

\section{INTRODUCTION}

MERICAN courts have understood clemency's importance
in the criminal justice system since early in the twentieth century. Clemency functions as an extrajudicial check on the discretion of courts and is needed partly because "[t]he administration of justice by the courts is not necessarily always wise or certainly considerate of circumstances which may properly mitigate guilt." Among the more concrete goals of clemency are enhanced fairness of criminal justice as well as correction of error. ${ }^{2}$ Not only is clem-

\footnotetext{
${ }^{1}$ Ex parte Grossman, 267 U.S. 87, 120-21 (1925).

${ }^{2}$ See Brian M. Hoffstadt, Normalizing the Federal Clemency Power, 79 Tex. L. Rev. 561, 571 (2001) (describing the purposes of Article II clemency authority); Elizabeth Rapaport, Staying Alive: Executive Clemency, Equal Protection, and the Politics of Gender in Women's Capital Cases, 4 Buff. Crim. L. Rev. 967, 1000 (2001) (describing the purposes of clemency as curbing the rigor of law, heeding individual equities, and correcting mistakes). For a broader discussion of the competing philosophic bases for clemency, see Michael A.G. Korengold et al., And Justice for Few: The Collapse of the Capital Clemency System in the United States, 20 Hamline L. Rev. 349, 350 (1996) (identifying "four broad categories" of rationales for clemency). See generally
} 
ency integral to the administration of justice, but also the criminal justice system relies on clemency. ${ }^{3}$

While playing an important role in the criminal justice system generally, clemency fulfills an especially crucial function in the death penalty context. The United States Supreme Court has noted that a criminal system that includes the death penalty but lacks clemency would be "totally alien to our notions of criminal justice." As a death row inmate's execution date approaches and avenues for appeal dwindle, a clemency petition is usually a defendant's final plea for relief from state execution. Given the magnitude of the stakes involved, ${ }^{s}$ clemency decisions involving death row inmates warrant particular attention, and the importance of clemency has increased as the number of death sentences has risen. Yet an increase in the number of death sentences has coincided with a decrease in the number of defendants removed from death row through clemency. ${ }^{6}$

States committed to the death penalty must take clemency seriously. To do so, states must acquire an accurate understanding of how it operates and how it is distributed. Surprisingly little is known about how clemency is used in practice, however. Crucial empirical questions persist, including whether the use of clemency varies by state, implicating issues of fairness and consistency. Given the extraordinary latitude afforded clemency decisions and the absence of uniform standards, some level of variation among states is to be expected,' but within this great zone of discretion lurks the

Kathleen Dean Moore, Pardons: Justice, Mercy, and the Public Interest (1989) (examining philosophical bases for the various genres of pardons).

${ }^{3}$ See Herrera v. Collins, 506 U.S. 390, 415 (1993) (noting that "[e]xecutive clemency has provided the 'fail safe' in our criminal justice system"); see also Moore, supra note 2, at 131 (stating that the pardon provides a backup to the safeguards built into the legal system so that "only those who deserve to be punished are punished and only so much as they deserve").

${ }^{4}$ Gregg v. Georgia, 428 U.S. 153, 200 n.50 (1976).

${ }^{5}$ The irrevocability of a death sentence distinguishes it from any other form of punishment. E.g. Furman v. Georgia, 408 U.S. 238, 306 (1972) (Stewart, J., concurring) ("The penalty of death differs from all other forms of criminal punishment ... in its total irrevocability.").

${ }^{6}$ See infra Tables 1 and 3; see also Korengold et al., supra note 2, at 351 (noting that the "abrupt" decline in clemency grants after 1976 created a "void in the capital system").

${ }^{7}$ See Daniel T. Kobil, The Quality of Mercy Strained: Wresting the Pardoning Power from the King, 69 Tex. L. Rev. 569, 604-11 (1991) (noting that very few states 
potential for mischief. Indeed, conventional wisdom suggests that the use of clemency-similar to the administration of the death penalty itself-is both arbitrary and uneven because of the influence of such factors as gender, race, and politics. ${ }^{8}$

Another related but distinct question is whether variations in how states structure clemency authority influence its use. States typically vest clemency authority in the governor, an administrative agency or board, or some blend of the two. 'To the extent that political factors influence clemency decisions, this influence should be greatest in states that vest governors with plenary clemency authority. ${ }^{10}$ That is, both conventional wisdom and theory predict that political forces are more likely to influence states with an executive rather than an administrative model of clemency authority. ${ }^{11}$

have developed and promulgated statutory or administrative guidelines governing the use of clemency); Steve Woods, Comment, A System Under Siege: Clemency and the Texas Death Penalty After the Execution of Gary Graham, 32 Tex. Tech. L. Rev. 1145 , 1158-60 (2001) (discussing constitutional restrictions on governors' decisions to grant clemency).

${ }^{8}$ See, e.g., Daniel T. Kobil, Chance and the Constitution in Capital Clemency Cases, 28 Cap. U. L. Rev. 567, 567 (2000) (suggesting that the use of clemency in the death penalty context is "abused" and "arbitrary," and concluding that clemency is a "flawed vehicle for achieving justice"). For relevant public opinion on this issue, see Jonathan Alter, The Death Penalty on Trial, Newsweek, June 12, 2000, at 24, 27 (discussing a poll conducted by Princeton Survey Research Associates indicating that $55 \%$ of respondents felt clemency decisions were based upon political considerations).

${ }^{9}$ See infra Table 1.

${ }^{10}$ To be sure, one of the most recent and dramatic episodes involved the questionable use of clemency authority at the federal level by President Clinton. For a summary of former President Clinton's use of Article II pardon authority, see Gregory C. Sisk, Suspending the Pardon Power During the Twilight of a Presidential Term, 67 Mo. L. Rev. 13, 14-16 (2002) (describing some of Clinton's final pardons as "difficult or impossible to justify"). Similar, though admittedly less notorious, concerns with clemency have arisen in the state context and focus on governors' use of clemency. See, e.g., John Harwood, Bush May Be Hurt by Handling of Death-Penalty Issue, Wall St. J., Mar. 21, 2000, at A28 (then-Governor George W. Bush); George E. Jordan, Lawyer: Execution a Disgrace, Newsday, May 4, 1992, at 19 (expressing outrage at then-Governor Clinton's refusal to grant clemency to Ricky Rector). More recently, activists have advocated death penalty moratoriums. See, e.g., Paul Schwartzman, Glendening Proposes Study of Executions, Wash. Post, Feb. 9, 2000, at B2 (discussing the decision of then-Governor Glendening to set aside $\$ 250,000$ in the state budget to study Maryland's death penalty).

${ }^{11}$ See Kobil, supra note 7, at 607-11 (arguing that the most important factor influencing a governor's use of clemency authority appears to be "widespread support of influential individuals in the community"); Korengold et al., supra note 2, at 363-64. 
My concerns about clemency's role and application reflect an assumption that clemency should neither reside wholly apart from the law nor be unconcerned with distributional issues. To be sure, other plausible assumptions about clemency and its role exist. For some, clemency is a benevolent virtue, governed by little more than fate, which the law should simply accept. ${ }^{12}$ For others, clemency should be meted out to fulfill an array of more pragmatic purposes-such as correction of error-to address traditional concerns about arbitrariness and capriciousness. ${ }^{13}$

Questions of distribution should be relevant even under alternative-perhaps inherently competing-conceptions of clemency. The Supreme Court has made quite clear that clemency plays an integral role in the death penalty process. ${ }^{14}$ Consequently, some level of concern over distributional questions endures. Moreover, while granting an extraordinarily wide discretionary berth, the Supreme Court has hinted at the contours of due process boundaries beyond which it will not permit clemency decisionmakers to cross. ${ }^{15}$ Similarly, if clemency were truly administered on a basis wholly outside of law and akin to "'gentle rain from heaven," "16 one would expect to find the outcome of clemency petitions to distribute randomly. As I demonstrate, however, clemency decisions in the death row setting are not randomly distributed. ${ }^{17}$ At a more practical level, although clemency seeks to accomplish a wide array of goals, correction of error is surely among the most important and obvious of them. ${ }^{18}$ Finally, it bears repeating that I confine my analysis of clemency to the death row context. Such a context places even

\footnotetext{
${ }^{12}$ For a helpful discussion, see Stephen P. Garvey, "As the Gentle Rain from Heaven": Mercy in Capital Sentencing, 81 Cornell L. Rev. 989, 991 n.10 (1996).

${ }^{13}$ See id. at 992 n.11.

${ }^{14}$ See infra Section I.B.2.

${ }^{15}$ See Ohio Adult Parole Auth. v. Woodard, 523 U.S. 272, 289 (1998) (O'Connor, J., concurring) (noting that "some minimal procedural safeguards apply to clemency proceedings" and suggesting that judicial review and intervention might be warranted if, for example, a clemency decision were determined by a "flipped ... coin" or if a state arbitrarily denied a prisoner any access to its clemency process).

${ }^{16}$ Garvey, supra note 12, at 989 (quoting William Shakespeare, The Merchant of Venice, act 4, sc. 1).

${ }^{17}$ See infra Part IV.

${ }^{15}$ See, e.g., Herrera v. Collins, 506 U.S. 390, 416-17 (1993) (noting that the defendant's proper forum for an actual innocence claim is at the clemency stage); see also infra Section I.B.2 and accompanying notes.
} 
more weight on clemency's error correction function. At the same time, I remain mindful that the administration of clemency in the death penalty context might not resemble its administration in other contexts. ${ }^{19}$

In this Article, I will explore how clemency is used with the benefit of data and examine its determinants for death row inmates. I use statistical analyses to examine which factors affect the decision to grant clemency. My analyses draw on three clusters of variables: defendant characteristics, political factors, and the structure of state clemency systems. My findings demonstrate that some common assumptions about clemency are correct, but others are either incorrect or misleading (or both). Contrary to conventional wisdom, a defendant's race and ethnicity did not influence clemency decisions, but conventional wisdom is correct with respect to gender: Female defendants were far more likely to receive clemency than their male counterparts. Unfortunately, the influence of race and gender in other, earlier stages of the death penalty process complicates explanations for the absence of race and the persistence of gender as factors at the clemency stage.

Also contrary to public perception, none of the political factors emerged as influential, ${ }^{20}$ although many structural factors did affect clemency decisions in the expected directions. States that empower administrative boards with clemency authority were more likely to grant clemency than states that relied on exclusive executive authority. Regionality and time also played a role: Clemency grants were less likely both in southern states and after 1984 .

Overall, these findings cast a troubling light on the use of clemency for defendants facing execution. More importantly, they provide additional support for the contention that the death penalty is both arbitrary and inconsistent. ${ }^{21}$

\footnotetext{
${ }^{19}$ Indeed, a comparison between clemency in the death row and non-death row contexts deserves careful study.

${ }^{20}$ Moreover, this result holds even when I examine only those states that grant their governors sole clemency authority. See infra Section IV.E. and Table 4.

${ }^{21}$ See Furman v. Georgia, 408 U.S. 238, 248-50, 249 n.11 (1972) (Douglas, J., concurring) (noting the arbitrary and discriminatory application of the death penalty); James S. Liebman et al., A Broken System: Error Rates in Capital Cases, 1973-1995, at i-iv (2000) (arguing that error rates in capital cases undermine the death penalty's effectiveness); David C. Baldus et al., Racial Discrimination and the Death Penalty in the Post-Furman Era: An Empirical and Legal Overview, with Recent Findings from
} 
The death penalty and clemency contexts will be considered briefly in Part I. Prior empirical research on clemency will be described in Part II. Methodology and data will be described in Part III. A discussion of my results and their implications will be presented in Part IV. Finally, I will close with concluding remarks and comments about future research.

\section{DeAth Penalty and Clemency}

To better understand clemency's role within the death penalty context, it is important to understand how the death penalty and clemency have interacted over time. Three trends have shaped the broad contours of this interaction. First, jurors and judges impose the death penalty on a steadily increasing number of defendants. Second, states increasingly carry out death sentences and execute defendants. Third, the use of clemency as a vehicle to remove defendants from death row has declined. These trends emerged at roughly the same time, and their interactions increased the stress imposed upon clemency's role within the death penalty context.

\section{A. Death Penalty}

Americans continue to support the use of the death penalty. ${ }^{22}$ While the percentage of people across the country favoring the

Philadelphia, 83 Cornell L. Rev. 1638, 1658 n.61, 1660 n.69, 1742-45 (1998) (arguing that the death penalty is biased); Stephen B. Bright, Will the Death Penalty Remain Alive in the Twenty-first Century?: International Norms, Discrimination, Arbitrariness, and the Risk of Executing the Innocent, 2001 Wis. L. Rev. 1, 2 (arguing that the death penalty is applied in a discriminatory manner and risks executing innocents); Samuel R. Gross, The Risks of Death: Why Erroneous Convictions are Common in Capital Cases, 44 Buff. L. Rev. 469 (1996) [hereinafter Gross, Risks of Death] (arguing that the death penalty is prone to error); Samuel R. Gross, Still Unfair, Still Arbitrary-But Do We Care?, 26 Ohio N.U. L. Rev. 517 (2000) (arguing that the death penalty is unevenly applied); Scott E. Sundby, The Lockett Paradox: Reconciling Guided Discretion and Unguided Mitigation in Capital Sentencing, 38 UCLA L. Rev. 1147 (1991) (arguing that restraints on state imposition of death penalty are weakening); Steve Mills et al., Shadows of Doubt Haunt Executions: 3 Cases Weaken Under Scrutiny, Chi. Trib., Dec. 17, 2000, $\$ 1$, at 1 (same).

${ }^{22}$ See Theodore Eisenberg et al., The Deadly Paradox of Capital Jurors, 74 S. Cal. L. Rev. 371, 372 (2001) [hereinafter Eisenberg et al., Deadly Paradox] (characterizing public support for the death penalty as "wide, but perhaps not deep"). Further complicating the matter is the fact that public support for the death penalty varies among racial and ethnic groups and between genders. See Theodore Eisenberg et al., Forecasting Life and Death: Juror Race, Religion, and Attitude Toward the Death Pen- 
death penalty for convicted murderers has varied to some degree over time and has declined slightly of late, over the past decade at least $65 \%$ of those surveyed by Gallup voiced their support for capital punishment. ${ }^{23}$ The salience of the death penalty issue is reflected in presidential campaigns. Commentators point to a single death penalty question posed by CNN broadcaster, Bernard Shaw, during a presidential candidate debate between Michael Dukakis and George Bush as pivotal in ensuring the Dukakis campaign's demise and fueling popular support for expanding the scope of the federal death penalty. ${ }^{24}$

Recent evidence, however, points to an emerging erosion of public support for the death penalty, however, although critics are quick to point out that survey results are influenced by the types of questions posed and words used. ${ }^{25}$ Likewise, judicial tolerance of the death penalty has waned recently. Although the Supreme Court has concluded that the imposition of the death penalty does not offend the Constitution, ${ }^{26}$ at least one federal district court recently concluded that the federal death penalty is unconstitu-

alty, 30 J. Legal Stud. 277, 277 (2001) [hereinafter Eisenberg et al., Forecasting Life and Death] (citing studies finding varying support).

${ }^{23}$ During the past decade, the percentage of adults supporting the death penalty for a person convicted of murder has ranged from a high of $80 \%$ (in 1994) to a low of $65 \%$ (in 2001). See Death Penalty, Gallup Poll, at http://www.pollingreport.com/ crime.htm\#Death (last visited Oct. 29, 2002) (on file with the Virginia Law Review Association); see also Eisenberg et al., Deadly Paradox, supra note 22, at 372 n.1 (summarizing polling data); Samuel R. Gross \& Phoebe C. Ellsworth, Second Thoughts: Americans' Views on the Death Penalty at the Turn of the Century, in Beyond Repair?: America's Death Penalty 8, 10 \& fig.1 (Stephen P. Garvey ed., 2002) (same).

${ }^{24}$ See, e.g., George Kannar, Federalizing Death, 44 Buff. L. Rev. 325, 325 (1996) (citing The Presidential Debate: Transcript of the Second Debate Between Bush and Dukakis, N.Y. Times, Oct. 14, 1988, at A14); Roger Simon, Death-Penalty Question Was Death Knell for Dukakis, Seattle Times, Nov. 6, 1990, at F1.

${ }^{25}$ See, e.g., Jeffrey M. Jones, The Death Penalty, Gallup.com, at http://www.gallup.com/poll/analysis/ia020830iii.asp?Version=p (Aug., 2002) (on file with the Virginia Law Review Association) (indicating that the percentage of respondents in favor of the death penalty dropped from $72 \%$ to $52 \%$ when the option was given to choose life without parole); see also Eisenberg et al., Deadly Paradox, supra note 22 , at 372 n.2 (listing further sources that summarizing polling data); Gary Langer, Life or Death?: Poll: More Americans Still Favor Death Penalty, ABCNews.com, at http://abcnews.com/sections/us/DailyNews/deathpenalty_poli020507 .html (May 7, 2002) (observing that support falls from $65 \%$ to $46 \%$ when given the alternative of life without parole).

${ }^{26}$ See, e.g., Gregg v. Georgia, 428 U.S. 153 (1976). 
tional. ${ }^{27}$ Moreover, recent Supreme Court decisions have narrowed the zone of constitutionally acceptable state executions. ${ }^{28}$ Some commentators see these recent decisions as reflecting increased public unease with the death penalty. ${ }^{29}$

That capital punishment exists at all in the United States is notable, principally because a majority of nations have either abolished or declined to use the death penalty. ${ }^{30}$ Among western, industrialized nations, America finds itself in a diminishing minority. ${ }^{31}$ During the past decade the number of countries reducing or eliminating state-enforced death has averaged three per year. ${ }^{32}$

America's use of capital punishment not only sets it apart from many other nations, but also endures as a point of discomfort in diplomatic and international law contexts. The United Nations High Commissioner for Human Rights, Mary Robinson, describes the increasing use of the death penalty in the United States (and elsewhere) as a "matter of serious concern ... [that] runs counter to the international community's expressed desire for the abolition of the death penalty." ${ }^{33}$ The application of the death penalty to

${ }^{27}$ United States v. Quinones, 205 F. Supp. 2d 256 (S.D.N.Y. 2002), rev'd, 313 F.3d 49 (2d Cir. 2002), reh'g denied, 317 F.3d 86 (2d Cir. 2003). In Quinones, the United States District Court for the Southern District of New York held the Federal Death Penalty Act unconstitutional, but the United States Court of Appeals for the Second Circuit later reversed this holding on appeal. Id.

${ }^{2 s}$ See Ring v. Arizona, 122 S. Ct. 2428 (2002) (concluding that preclusion of jurors from assessing possible aggravating factors in a capital trial is unconstitutional); Atkins v. Virginia, 122 S. Ct. 2242 (2002) (precluding the execution of mentally retarded defendants).

${ }^{2 y}$ See, e.g., Linda Greenhouse, Citing 'National Consensus,' Justices Bar Death Penalty for Retarded Defendants, N.Y. Times, June 21, 2002, at A1.

${ }^{31}$ According to a recent Amnesty International report, 111 of the 195 nations surveyed have abolished capital punishment in law or practice. See Amnesty International, Abolitionist and Retentionist Countries, at http://www.web.amnesty.org/ rmp/dplibrary.nsf/ba4275cdead20d858025677e0059735b/daa2b602299dded0802568810 050f6b1 (last visited Oct. 9, 2002) [hereinafter Amnesty Report] (on file with the Virginia Law Review Association).

${ }^{31}$ See The Rights and Wrongs, Economist, May 12, 2001, at 11 (noting that, by administering the death penalty, the United States places itself "alongside countries such as Congo, Iran and China").

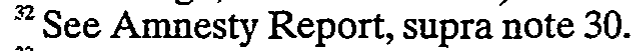

${ }^{33}$ Jeremy Lehrer, Robinson's opinions on human rights, Hum. Rts. Mag., Summer 1998, at 10 (quoting Mary Robinson), available at http://www.abanet.org/ $\mathrm{irr} / \mathrm{hr} / \mathrm{sum} 98 \mathrm{lehrer1.html}$ (last visited Jan. 11, 2003); see also Richard C. Dieter, Death Penalty Info. Ctr., International Perspectives on the Death Penalty: A Costly Isolation for the U.S. (1999) (explaining the international implications of the trend in the 
persons younger than eighteen years old has proven to be an especially contentious issue at international and diplomatic levels. ${ }^{34}$

Setting aside debates about the evolving strength and depth of public and international support for the death penalty, Figure 1 illustrates an unmistakable increase in the number of death sentences imposed in the United States over time. The striking jump from forty-four death sentences in 1973, to 160 in 1974, and to 318 in 1975 can be attributed to a lagged response by states to the Supreme Court's Furman v. Georgia decision in $1972 .{ }^{35}$ In Furman, the Court concluded that the states' administration of the death penalty was unconstitutional. States that wished to continue executing capital criminals worked quickly to amend their statutes in a manner that responded to the Court's concerns. As a result, "nearly every aspect of death penalty legislation has been revised since 1972." ${ }^{\prime 36}$ In 1976, the Court signaled its willingness to tolerate the death penalty by approving Georgia's death penalty statute. ${ }^{37}$ By 1983, the constitutional parameters within which states needed to structure their death penalty processes became relatively clear. ${ }^{38}$

United States towards expanding the classes of crimes subject to capital punishment), at http://www.deathpenaltyinfo.org/internationalreport.html (last visited Oct. 29, 2002).

${ }^{34}$ See generally Cele Hancock, The Incompatibility of the Juvenile Death Penalty and the United Nation's Convention on the Rights of the Child: Domestic and International Concerns, 12 Ariz. J. Int'l \& Comp. L. 699 (1995) (arguing that the United States must reserve its sovereign right to manage its juvenile crime problem).

${ }^{35} 408$ U.S. 238 (1972) (finding the death penalty unconstitutional, partly because of its arbitrary and discriminatory application). Notably, the Bureau of Justice Statistics recently reported that the total number of executions in 2000 , eighty-five, was thirteen fewer than the number of executions in 1999. See Bureau of Justice Statistics, U.S. Dep't of Justice, Capital Punishment 2000, at 1 (2001) [hereinafter BJS 2000].

${ }^{36}$ William Alex Pridemore, An Empirical Examination of Commutations and Executions in Post-Furman Capital Cases, 17 Just. Q. 159, 159 (2000).

${ }^{37}$ See Gregg v. Georgia, 428 U.S. 153 (1976).

${ }^{38}$ Professors Blume and Eisenberg note that by 1983 the Supreme Court had dismantled most of the death penalty procedural restrictions imposed by Gregg and Furman. See John Blume \& Theodore Eisenberg, Judicial Politics, Death Penalty Appeals, and Case Selection: An Empirical Study, 72 S. Cal. L. Rev. 465, 480 n.53 (1999); see also Samuel R. Gross \& Robert Mauro, Death and Discrimination: Racial Disparities in Capital Sentencing 13 n.30 (1989) (citing the confused case law that emerged following Gregg and Furman). 
Figure 1: Imposition of the Death Penalty, 1973-999

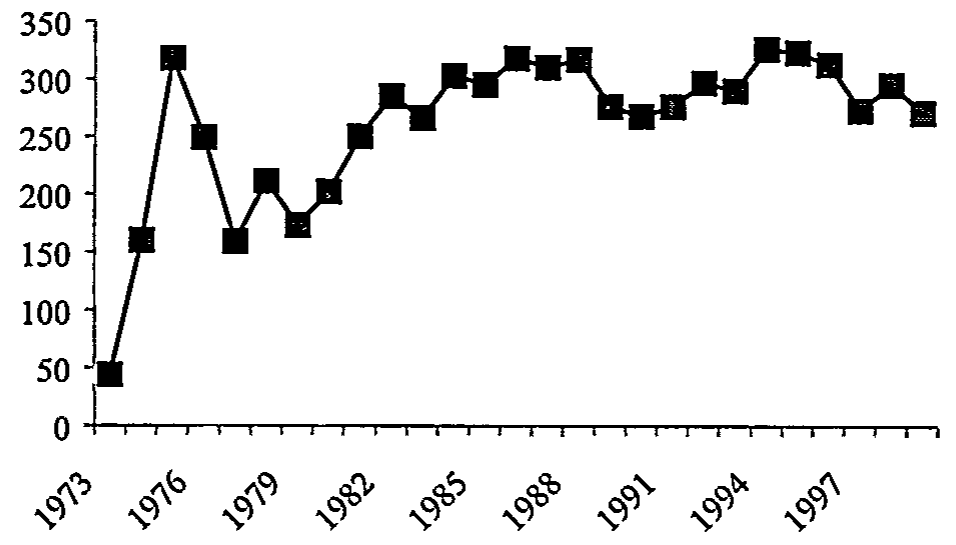

Increases in the number of death sentences do not necessarily lead to proportional increases in executions. It is one thing for a court to impose the death penalty and quite another for a state to carry out an execution. ${ }^{40}$ During most of the twentieth century, however, not only was the death penalty imposed with increasing regularity, but states likewise carried out executions with increasing regularity. Figure 2 illustrates that the number of inmates put to death by the states increased steadily over time. The dramatic jump in the number of executions between 1983 (five executions) and 1984 (twenty-one executions) corresponds to the earlier jump in the number of defendants receiving the death penalty ${ }^{41}$ combined with increasingly limited access to the appeals process. ${ }^{42}$ Professor Pridemore notes that approximately one-half of all executions during the post-Furman era took place between 1992 and 1995. ${ }^{43}$

3" The results presented in this Figure are based on the available universe of data published by the Bureau of Justice Statistics $(\mathrm{N}=7,416)$. See Bureau of Justice Statistics, U.S. Dep't of Justice, Capital Punishment in the United States 1973-1999 (InterUniv. Consortium for Political and Soc. Research No. 3201, 2001) [hereinafter BJS]; see also infra Section III.B.1 and note 95.

${ }^{4 / 3}$ As of December 31, 1999, 3,527 defendants remained on death row. See infra Section III.B.1 and note 99.

${ }^{41}$ See supra Figure 1.

${ }^{42}$ See Pridemore, supra note 36 , at 160.

${ }^{43}$ See Pridemore, supra note 36 , at 175 (attributing the increase in the rate of executions to governors overcoming legal "jittery[-ness]" following Furman). 
Figure 2: State Executions, 1977-994

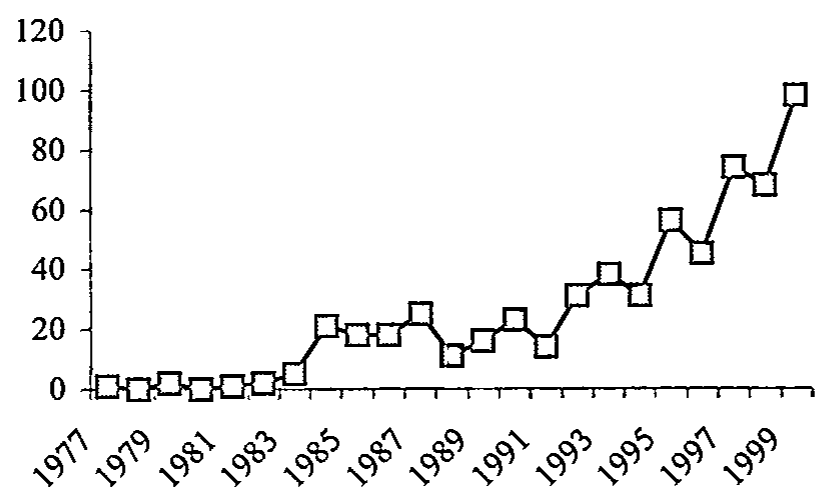

B. Clemency

While jurors and judges imposed the death penalty and states carried out executions with increasing frequency over time, the use of clemency to remove inmates from death row declined. Figure 3 illustrates the frequency with which states have granted clemency from 1973 through 1999.

\footnotetext{
${ }^{44}$ See BJS, supra note 39. Although the data used to generate Figure 2 spans 1973 through 1999, no executions took place between 1973 through 1976.
} 
Figure 3: Clemency Grants, 1973-99

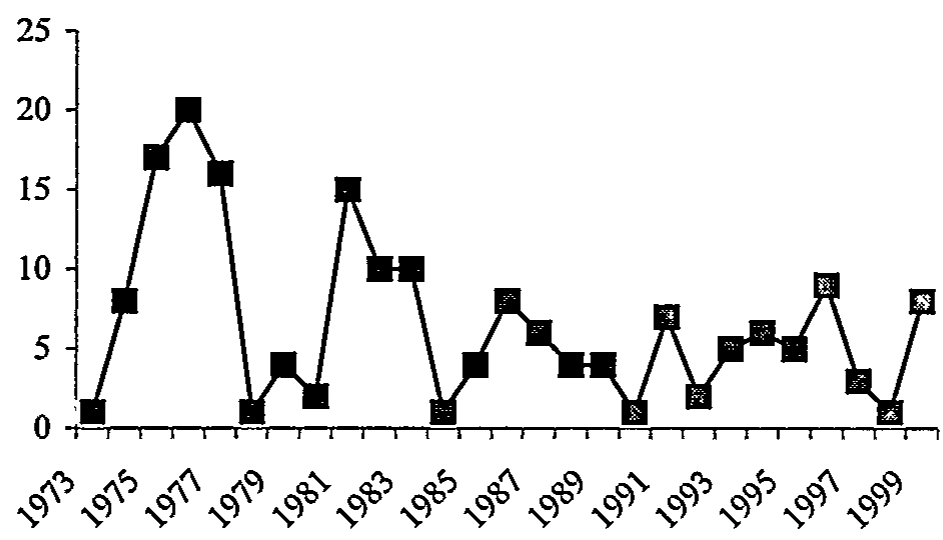

Unlike the trends illustrated in Figures 1 and 2, the trend in Figure 3 is less stable over time. Some of this instability can be attributed to clemency's infrequent use. Notwithstanding the absence of a clear, uninterrupted trend, Figure 3 conveys a general sense of decline over time. Although many commentators have noted this decline, few have tried to explain it. ${ }^{46}$ Explanations range from the political $^{47}$ to the conceptual. ${ }^{48}$ Regardless of the precise cause, the interaction of the declining use of executive clemency and the increasing frequency with which the death sentence is both imposed and carried out places stress on clemency's role within the death penalty context. The situation is exacerbated by a diminished

\footnotetext{
${ }^{45}$ See BJS, supra note 39.

${ }^{45}$ For one notable attempt to explain this decline, see Korengold et al., supra note 2, at 351 (describing reasons for the "abrupt" decline in clemency grants after 1976).

${ }^{47}$ See, e.g., Korengold et al., supra note 2, at 363 (arguing that "political expediency" is the "most obvious and accurate explanation for the decrease in clemency grants"); Mark Tushnet \& Larry Yackle, Symbolic Statutes and Real Laws: The Pathologies of the Antiterrorism and Effective Death Penalty Act and the Prison Litigation Reform Act, 47 Duke L.J. 1, 1 (1997) ("No politician in recent memory has lost an election for being too tough on crime.").

${ }^{43}$ See Bruce Ledewitz \& Scott Staples, The Role of Executive Clemency in Modern Death Penalty Cases, 27 U. Rich. L. Rev. 227, 227 (1993) (arguing that while public understanding of the death penalty has evolved over time, public understanding of executive clemency has remained static, thereby contributing to a decrease in the granting of clemency for death row inmates); Liebman et al., supra note 21 (arguing that death row removals are related to the error rate: The higher the error rate, the higher the removal rate).
} 
availability of courts to review death row appeals in both the state and federal systems. ${ }^{49}$ These factors, independently and collectively, make clemency authority "more important than ever."

\section{Clemency's Unique Role}

Clemency is an extrajudicial measure designed to accomplish multiple goals. Some of these goals, broadly stated, include the amelioration of miscarried justice and the correction of legal errors. The increase in the number of death sentences and executions, combined with the decrease in the number of successful clemency grants, makes even more important clemency's ability to function as designed. Degradation in the administration of clemency warrants attention, especially given the implications for one of clemency's responsibilities: error correction. As Professor Frank Carrington notes, the need for clemency's error correction function is at its highest in the death penalty setting. ${ }^{51}$

The possibility of error plaguing the administration of the death penalty-in its most extreme form, the possibility that actually innocent defendants might be sentenced to death and executed-is not an abstract background risk. ${ }^{52}$ The risk of executing an innocent person poses the single most serious, largely unanswerable chal-

\footnotetext{
${ }^{49}$ See Pridemore, supra note 36 , at 160 .

${ }^{50}$ See Am. Bar Ass'n Section of Individual Rights and Responsibilities, Death Without Justice: A Guide for Examining the Administration of the Death Penalty in the United States, 63 Ohio St. L.J. 487, 510 (2002) (arguing that clemency power is "more important than ever" partly because of its declining application and the diminished appellate options for defendants).

${ }^{51}$ Frank G. Carrington, Neither Cruel Nor Unusual 123 (1978) (arguing that where death sentences are imposed after a conviction, clemency plays a role when "there is the slightest doubt of guilt (even after conviction)").

${ }^{52}$ For a more detailed discussion of this point, see Ronald J. Tabak, Finality Without Fairness: Why We Are Moving Towards Moratoria on Executions, and the Potential Abolition of Capital Punishment, 33 Conn. L. Rev. 733, 733-39 (2001) (discussing the impact of DNA testing).

Also, as of January 11, 2003, the Innocence Project-a nonprofit legal clinic at the Benjamin N. Cardozo School of Law that handles only cases where post-conviction DNA evidence raises actual innocence issues-had uncovered 123 cases where individuals were convicted despite their actual innocence. See Innocence Project, at http://www.innocenceproject.org/index.php (last visited Jan., 11, 2003) (on file with the Virginia Law Review Association). Eight of the post-conviction exonerations involved inmates on death row. See Barry C. Scheck, Preventing the Execution of the Innocent: Testimony Before the Senate Judiciary Committee, 29 Hofstra L. Rev. 1165,1165 (2001).
} 
lenge to capital punishment. ${ }^{53}$ As Professor Gross notes, it is one thing to satisfy the retributive dimension of criminal law by executing a guilty defendant, but it is quite another to do so by executing an innocent defendant or one who might be innocent. ${ }^{54}$ When the scent of error (or even the possibility of error) is present, clemency provides one obvious antidote. To be sure, clemency's record as a "fail-safe" death by the state is the subject of debate ${ }^{.6}$ even the Court acknowledges that clemency is not an infallible guard against mistake. ${ }^{57}$ Infallibility aside, clemency is uniquely positioned to correct legal error.

\section{The Criminal Justice System's Reliance on Clemency}

Not only does clemency perform critical functions for the criminal justice system, but courts explicitly rely on the possibility of clemency when applying rules of criminal law. In Herrera $v$. Collins, the Supreme Court ruled that federal habeas corpus is not available for defendants' pleas of actual innocence absent an independent constitutional violation. ${ }^{58}$ The Court concluded that federal habeas relief is a proper vehicle only for disputed constitutional claims. The Court went on to reject Herrera's assertion that the Eighth and Fourteenth Amendments forbid the execution of an actually innocent defendant absent a proper forum for the consideration of facts bearing on guilt. ${ }^{59}$ Part of the Court's reasoning for

${ }^{53}$ For formal explications of this point, see Richard O. Lempert, Desert and Deterrence: An Assessment of the Moral Bases of the Case for Capital Punishment, 79 Mich. L. Rev. 1177, 1225-31 (1981); Margaret Jane Radin, Cruel Punishment and Respect for Persons: Super Due Process for Death, 53 S. Cal. L. Rev. 1143 (1980).

${ }^{54}$ Gross, Risks of Death, supra note 21, at 471.

${ }^{s 5}$ Moore, supra note 2, at 131.

${ }^{56}$ Compare Hugo Adam Bedau \& Michael L. Radelet, Miscarriages of Justice in Potentially Capital Cases, 40 Stan. L. Rev. 21 (1987) (discussing cases where defendants believed to be innocent were not granted clemency and were put to death), with Stephen J. Markman \& Paul G. Cassell, Protecting the Innocent: A Response to the Bedau-Radelet Study, 41 Stan. L. Rev. 121, 121 (1988) (challenging the argument made by Professors Bedau and Radelet as failing to demonstrate that there was "an unacceptable risk of executing the innocent").

${ }^{57}$ See Herrera v. Collins, 506 U.S. 390, 415 n.15 (1993).

ss Id. at 400.

${ }^{59}$ Id. at 417-29. To be fair, however, all of the Justices concurred that the execution of an actually innocent defendant would violate the Constitution. Id. at $417-41$, and a 
narrowing the sweep of federal habeas corpus flowed from the Court's belief that the defendant, Herrera, could use Texas's clemency process as a forum to assert an actual innocence claim. ${ }^{60}$ Indeed, the Court went on to note that clemency "is the historic remedy for preventing miscarriages of justice where judicial process has been exhausted." $" 61$

\section{The Structure of Clemency Authority}

The structure of a state's clemency authority influences how clemency is applied. To be sure, any effort to structure statutorily an extrajudicial measure like clemency quickly becomes a dilemma. The U.S. Attorney General's manual on release procedures illustrates the contradiction inherent in the clemency doctrine. "[The pardon authority] has never been crystallized into rigid rules. Rather, its function has been to break rules." ${ }^{62}$ Within this vast, expressly delegated discretion are significant differences in perceptions about how mercy should be granted and in the actual exercise of clemency. Some recoil at the necessary degree of latitude involved and view the act of pardoning anachronistic in a legal regime that dwells on rules and is wary of discretion. ${ }^{63}$

Clemency authority at the federal level, tucked away in Article II of the Constitution, reflects our common law heritage and arcs backward to royal prerogative. The constitutional Framers viewed

majority of the Justices concluded that Herrera had not proven innocence. Id. at 41729.

${ }^{60}$ Id. at 416-17; see also 37 Tex. Admin. Code $\S 143.2$ (West 2002) (setting forth three statutory requirements for consideration when reviewing a pardon application on the grounds of innocence).

${ }^{61}$ Herrera, 506 U.S. at 411-12; see also Moore, supra note 2, at 131.

${ }^{62} 3$ U.S. Dep't of Justice, Attorney General's Survey of Release Procedures: Pardon 295 (1939), quoted in Margaret Colgate Love, Of Pardons, Politics and Collar Buttons: Reflections on the President's Duty to be Merciful, 27 Fordham Urb. L.J. 1483, 1483 (2000).

${ }^{63}$ Congress's enactment of the Sentencing Guidelines can be viewed as yet another example of the federal government's wariness of governmental discretion, in this instance as it bears on judges' sentencing authority. For a general discussion, see Gregory C. Sisk, Michael Heise \& Andrew P. Morriss, Charting the Influences on the Judicial Mind: An Empirical Study of Judicial Reasoning, 73 N.Y.U. L. Rev. 1377, 139698 (1998) (describing reasons for the emergence of the federal Sentencing Guidelines). 
pardons as a public act of office rather than a private act of grace. ${ }^{64}$ The federal Constitution grants the President plenary pardon authority, ${ }^{65}$ reflecting the Framers' belief that "the sense of responsibility is always strongest in proportion as it is undivided."

Clemency at the state level largely mimics its federal counterpart. Perhaps informed by the federal Constitution, many states assign to their governors sole clemency decisionmaking authority. ${ }^{67}$ Unlike the delegation provided in Article II, however, other states assign clemency decisionmaking power to administrative boards. ${ }^{6}$ Most states seek to capture the benefits flowing from both the executive and administrative models through a third variation: a hybrid blend of the two. ${ }^{69}$ Although the structure of clemency decisionmaking authority varies by state, every state that presently uses the death penalty has either constitutional or statutory provisions for clemency. ${ }^{70}$

${ }^{64}$ See Edward S. Corwin, The President: Office and Powers 1787-1984, at 181 (Randall W. Bland et al. eds., $5^{\text {th }}$ rev. ed. 1984).

${ }^{65}$ Questions about the plenary nature of presidential pardon authority arise from time to time, as periodic controversies swirl. See, e.g., Iain R. McPhie, Symposium: Executive Privilege and the Clinton Presidency, Introduction, $8 \mathrm{Wm}$. \& Mary Bill Rts. J. 535, 538 (2000) (discussing the controversial pardons authorized by former President Clinton and describing his use as "aggressive-and sometimes abusive"); Sisk, supra note 10, at 14-16 (similar); Charles Babington, Puerto Rican Nationalists Freed From Prison, Wash. Post, Sept. 11, 1999, at A2 (similar); Eric Lichtblau, Clinton Won't Turn Over Records, L.A. Times, Sept. 17, 1999, at A14 (similar). For a discussion about Congress's role in supervising the President's use of pardon authority, see Jonathan Turley, Paradise Lost: The Clinton Administration and the Erosion of Executive Privilege, $60 \mathrm{Md}$. L. Rev. 205, 245 (2001) (rejecting the assertion that the President's pardon authority is purely plenary).

* The Federalist No. 74 (Alexander Hamilton).

${ }^{67}$ See infra Table 1.

"See infra Table 1.

${ }^{6 y}$ See infra Table 1.

${ }^{76}$ See Ala. Const. amend. 38; Ala. Code § 15-18-100 (1995); Ariz. Const. art. V, § 5; Ariz. Rev. Stat. Ann. \$\$ 31-443, 31-445 (West 2002); Ark. Const. art. VI, § 18; Ark. Code Ann. \$\$ 5-4-607, 16-93-204 (Michie 1987 \& Supp. 2001); Cal. Const. art. V, § 8; Cal. Gov't Code \$ 12030(a) (West 1992); Colo. Const. art. IV, § 7; Colo. Rev. Stat. $\S \S 16-17-101$ to 16-17-102 (2002); Conn. Const. art. IV, § 13; Conn. Gen. Stat. Ann. $\S 18-26$ (West 1988); Del. Const. art. VII, § 1; Del. Code Ann. tit. 29, § 2103 (1997); Fla. Const. art. IV, § 8; Fla. Stat. Ann. § 940.01 (West 2001); Ga. Const. art. IV, § 2, para. 2; Ga. Code Ann. \$\$ 42-9-20, 42-9-42 (1997 \& Supp. 2002); Idaho Const. art. IV, $\$ 7$; Idaho Code $\$ 67-804$ (Michie 2001); Idaho Code $\$ 20-240$ (Michie 1997); Ill. Const. art. V, § 12; 730; Ill. Comp. Stat. Ann. 5/3-3-13 (West 1997 \& Supp. 2002); Ind. Const. art. V, § 17; Ind. Code Ann. § 11-9-2-1 to 11-9-2-4 (Michie 2000 \& Supp. 2002); Ind. Code Ann. § 35-38-6-8 (Michie 1988 \& Supp. 2002); Kan. Const. art. I, § 7; Kan. 
As Table 1 illustrates, the thirty-two states that granted clemency between 1973 and 1999 reflect five major forms of clemencygranting authority. ${ }^{71}$ In the pure form of the executive model, the governor possesses sole clemency decisionmaking authority. The pure model is the most popular in this study (34\% of death-penalty states). Six states (19\%) use a variation of the pure form that grants the governor clemency authority but only after a nonbinding recommendation from an administrative board or advisory group. A third variation of the executive model-used by $31 \%$ of the states-vests clemency-granting authority in the governor but restricts its use absent an affirmative clemency recommendation from an administrative board or advisory group. Whether this variation is appropriately characterized as an example of the executive model warrants discussion. On the one hand, the governor,

Stat. Ann. § 22-3701 (1995 \& Supp. 2001); Ky. Const. § 77; La. Const. art. IV, § 5(E); La. Rev. Stat. Ann. § 15:572 (West 1992 \& Supp. 2002); Md. Const. art. II, § 20; Md. Code Ann., Corr. Serv. § 7-601 (1999); Miss. Const. art. V, § 124; Miss. Code Ann. $\S 47-5-115$ (2000); Mo. Const. art. IV, § 7; Mo. Ann. Stat. § 552.070 (West 2002); Mo. Ann. Stat. § 217.220 (West 1996); Mont. Const. art. VI, § 12; Mont. Code Ann. §§ 4623-301 to 46-23-316 (2001); Neb. Const. art. IV, § 13; Neb. Rev. Stat. §§ 83-1,127 to 83-1,132 (2000); Nev. Const. art. V, § 13; Nev. Rev. Stat. Ann. 213.080 (Michie 2000); N.H. Const. pt. 2, art. 52; N.H. Rev. Stat. Ann. § 4:23 (2001); N.J. Const. art. V, § 2, para. 1; N.J. Stat. Ann. §§ 2A:167-4 to 2A:167-12 (West 1985); N.M. Const. art. V, § 6; N.M. Stat. Ann. § 31-21-17 (Michie 2000); N.Y. Const. art. IV, § 4; N.Y. Exec. Law $\S \S 15-19$ (McKinney 2002); N.C. Const. art. III, § 5(6); N.C. Gen. Stat. §§ 147-23 to 147-25 (2000); Ohio Const. art. III, § 11; Ohio Rev. Code Ann. §§ 2967.01 to 2967.12 (Anderson 1996); Okla. Const. art. VI, § 10; Okla. Stat. Ann. tit. 21, § 701.11a (West 2002); Or. Const. art. V, § 14; Or. Rev. Stat. §§ 144.649-144.670 (1999); Pa. Const. art. IV, § 9; S.C. Const. art. IV, § 14; S.C. Code Ann. \$\$ 24-21-910 to 24-21-1000 (Law. Coop. 1989 \& Supp. 2001); S.D. Const. art. IV, § 3; S.D. Codified Laws \$§ 23A-27A-20 to 23A-27A-21, 24-14-1 (Michie 1988); Tenn. Const. Art. III, § 6; Tenn. Code Ann. $\S \S 40-27-101$ to 40-27-109 (1997 \& Supp. 2002); Tex. Const. art. IV, § 11; Tex. Code Crim. Proc. Ann. art. 48.01 (Vernon 1979 \& Supp. 2002); Utah Const. art. VII, § 12; Utah Code Ann. § 77-27-5.5 (1982 \& Supp. 2002); Va. Const. art. V, § 12; Va. Code Ann. § 53.1-230 (Michie 2002); Wash. Const. art. III, § 9; Wash. Rev. Code Ann. $\S 10.01 .120$ (West 2002); Wyo. Const. art. IV, § 5; Wyo. Stat. Ann. § 7-13-801 (Michie 2001).

${ }^{71}$ In addition to variation in how states structure clemency decisionmaking authority, variation also exists in each state's clemency procedures. For a summary, see Stephen E. Silverman, Note, There is Nothing Certain Like Death in Texas: State Executive Clemency Boards Turn a Deaf Ear to Death Row Inmates' Last Appeals, 37 Ariz. L. Rev. 375, 389-95 (1995) (surveying state clemency practices).

The thirty-two states included in this study account for $100 \%$ of the clemency grants and more than $95 \%$ of the death row population between 1973 and 1999 . See BJS, supra note 39 . 
as the state's titular head, assumes ultimate responsibility for the dispensation of clemency. After all, a governor may decide to ignore a recommendation for clemency. Governors, however, may not grant clemency absent board or group recommendation. The recommendation requirement serves as one check on a governor's use of executive authority. On the other hand, governors otherwise reluctant to grant clemency may endeavor to deflect political responsibility (or liability) for clemency onto the recommending board or agency. Although this form of a "blended" clemency decisionmaking model-vesting governors with clemency authority, but only upon the recommendation of a board-appears as if it could operate as a double-veto, in fact, it generated a sizeable number of clemency grants. In this context, the board serves as something loosely resembling a "nominating" committee.

Administrative models of clemency-granting authority are less common than the executive models. ${ }^{2}$ Fifteen percent of the states implement administrative models of clemency-granting authority. Six percent utilize a pure form of the administrative model in which a board or advisory group is solely vested with clemency decisional authority. Nine percent of the states similarly vest a board or advisory group with clemency authority, but the governor sits on the board. To be sure, the possibility that governors may seek to influence administrative boards' clemency decisions cannot be dismissed. Some commentators emphasize the role of the governor even in states with a pure administrative clemency model. ${ }^{73}$ Despite the implications for an administrative board's independence, however, distinctions separating the pure executive and administrative models retain much of their traction. No amount of formal or informal efforts to influence an administrative board's clemency decisions can alter the board's ultimate responsibility for its own decisions.

\footnotetext{
${ }^{72}$ In my study of the thirty-two states that granted clemency between 1973 and 1999, $84 \%$ of the states possess an executive model and $15 \%$ possess an administrative model. See BJS, supra note 39.

${ }^{73}$ See, e.g., Ledewitz \& Staples, supra note 48, at 228-29 (noting the influence of governors even in states with administrative clemency models).
} 
Table 1: Models of Clemency Authority and Clemency Grants by Authority ${ }^{74}$

\begin{tabular}{||c|c|c|c|}
\hline \multicolumn{1}{|c|}{ Model } & $\begin{array}{c}\% \\
\text { of } \\
\text { States }\end{array}$ & $\begin{array}{c}\% \text { on } \\
\text { Death } \\
\text { Row }\end{array}$ & $\begin{array}{c}\% \text { of } \\
\text { Clemency } \\
\text { Grants }\end{array}$ \\
\hline \hline Executive: & & & \\
(1) Gov. has sole authority. & 34 & 24.9 & 25.8 \\
$\begin{array}{l}\text { (2) Gov.-must have rec- } \\
\text { ommendation from bd. }\end{array}$ & 31 & 54.4 & 52.8 \\
$\begin{array}{l}\text { (3) Gov.-after non- } \\
\text { binding recommenda- } \\
\text { tion from bd. }\end{array}$ & 19 & 13.3 & 11.8 \\
$\begin{array}{l}\text { Administrative: } \\
\text { (4) Board has sole } \\
\text { authority }\end{array}$ & 6 & 4.4 & 5.6 \\
(5) Board-Gov. a member & 9 & 3.1 & 3.9 \\
$\quad$ (N) & 776 & 178 \\
\hline
\end{tabular}

Given the distribution of models among states that granted clemency, the results presented in Table 1 are not surprising. First, the percentage of clemency grants reflects the percentage of death row activity. Second, executive models generated the bulk $(90.4 \%)$ of the clemency grants. A closer look at the data reveals, however, that more than one-half of all clemency grants $(52.8 \%)$ came from states where governors possessed clemency authority but could not act absent a board or advisory group recommendation. ${ }^{75}$ More im-

\footnotetext{
${ }^{74}$ Percentages do not add up to one hundred because they have been rounded.

${ }^{75}$ It bears mention that although governors, administrative boards, or blends of both models possess enormous power in deciding whether clemency is to be granted and, if so, how clemency authority is exercised, clemency decisions have not entirely escaped the reach of the judiciary. The Supreme Court has at least hinted-however
} 
portant for this study is the observation that this distribution of clemency models bounded within a single context-clemency petitions from those on death row-permits exploration of whether the manner in which states structure clemency authority influences clemency decisions.

Indeed, the variation among the thirty-two states over a twentyseven year period generates an almost natural experimental design and permits a comparison of the three major clemency model forms: pure executive, pure administrative, and blended. Analysis of structural variables will reveal whether a clemency decisionmaking model exerts independent influence on clemency decisions and, if so, which model might be more prone to tilt against public opinion on the death penalty.

\section{PREVIOUS STUdies}

Empirical studies of clemency are scant; the few that exist are largely descriptive and anecdotal. ${ }^{76}$ The few existing studies of clemency tend to focus on defendants' characteristics ${ }^{77}$ and, to a lesser extent, political factors. ${ }^{78}$ Although scholars have called for exploration of the potential influence of clemency's structure on its

vaguely-at some due process concerns that implicate the executive authority in this context. See Ohio Adult Parole Auth. v. Woodard, 523 U.S. 272, 288-89 (1998) (O'Connor, J., concurring in part and concurring in the judgment).

${ }^{76}$ Professor Pridemore's study is an important exception. See Pridemore, supra note 36. Moreover, important empirical work considers variables influencing relief from death row for all possible reasons, including clemency. See, e.g., Blume \& Eisenberg, supra note 38; see also Ursula Bentele, The Death Penalty in Georgia: Still Arbitrary, 62 Wash. U. L.Q. 573 (1985) (analyzing Georgia's capital punishment system as applied in murder convictions); Michael L. Radelet \& Barbara A. Zsembik, Executive Clemency in Post-Furman Capital Cases, 27 U. Rich. L. Rev. 289 (1993) (discussing the declining frequency of commutations and the reasons underlying individual clemency decisions); Margaret Vandiver, The Quality of Mercy: Race and Clemency in Florida Death Penalty Cases, 1924-1966, 27 U. Rich. L. Rev. 315 (1993) (discussing the relationship between clemency decisions and the race of both defendants and victims).

$\pi$ See Pridemore, supra note 36 , at 170 tbl.2.

${ }^{78}$ Fred B. Burnside, Comment, Dying to Get Elected: A Challenge to the Jury Override, 1999 Wis. L. Rev. 1017 (exploring the influence of judicial elections on a judge's decision to override a jury's recommendation for life imprisonment in favor of death). 
use ${ }^{79}$ none, until this study, has considered defendant characteristics and political factors along with structural factors.

Professor Pridemore assessed clemency decisions between 1974 and 1995 and found that defendants who are older, male, sentenced in the South, and whose final disposition takes place during a gubernatorial election cycle were less likely to receive clemency. Other studies, exploring the impact of clemency decisions on homicide rates, found that, as economic theory predicts, clemency grants increase and executions decrease homicide rates. ${ }^{81}$ Finally, findings from studies that have compared decisions made by governors with decisions made by administrative bodies generally comport with what theory predicts: Administrative boards are more politically insulated and therefore more likely than governors to resist public opinion and remove a defendant from death row. ${ }^{82}$

This study builds on existing research in important ways. The Pridemore study is limited to data from 1974 to 1995. Other clemency studies focus on single states. ${ }^{83}$ Data in this study are drawn from all thirty-two states that have granted clemency or executed inmates (or both), and cover the period from 1973 to 1999. In addition, this study includes two additional clusters of variables-

${ }^{79}$ Pridemore, supra note 36 , at 178 n.15.

${ }^{80}$ Id. at $171-73$.

${ }^{81}$ H. Naci Mocan \& R. Kaj Gittings, Removals from Death Row, Executions and Homicides 5 (May 2002) (unpublished manuscript, on file with the Virginia Law Review Association) (finding that executions decrease and pardons increase homicide rates). To be sure, much more empirical work on the relationships among executions, pardons, and homicides is needed before any firm conclusions are possible.

${ }^{8}$ For a discussion of the relevant theory, see, e.g., Alan Brinkley, The End of Reform: New Deal Liberalism in Recession and War 63 (1995) (noting that New Deal liberals felt a need for "independent executive agencies ... [staffed with] expert administrators, insulated as far as possible from political pressures"); Mark Seidenfeld, A Civic Republican Justification for the Bureaucratic State, 105 Harv. L. Rev. 1511, 1542 (1992) (emphasizing that most administrative agencies "fall between the extremes of the politically over-responsive Congress and the over-insulated courts"). For tentative empirical support, see Thomas L. Austin \& Don Hummer, The Effect of Legal and Extra-Legal Variables on the Recommending and Granting of a Pardon, 22 Law \& Pol'y 49 (2000) (finding that pardon recommendations in Pennsylvania from an administrative board are based more on an individualized decisionmaking model. whereas the governor's decision to accept or reject the board's recommendation follows a more standardized decisionmaking model); Korengold et al., supra note 2, at 350-51.

${ }^{83}$ For example, the Austin and Hummer study, supra note 82 , is limited to a governor's decision to accept a clemency board's recommendation within Pennsylvania. 
political and structural - that have been identified as important yet largely ignored in the academic literature and research. Recent attention to political factors thought to influence clemency decisions was fueled by former President Clinton's unusual and controversial use of his pardon authority during his administration. ${ }^{84}$ Similarly, outgoing Illinois Governor Ryan's recent imposition of a death penalty moratorium and subsequent grant of clemency to all 167 inmates on Illinois's death row received significant public attention. ${ }^{s s}$ The manner in which a state structures clemency authority also has been suggested as a possible variable influencing clemency decisions. $^{86}$

The influence of political and, to a lesser extent, structural factors on clemency decisions has long been assumed. ${ }^{87}$ Questions about whether political factors can explain variation in the application of clemency deserve particular attention. These political factors include a governor's background, age, education, political party, religion, election, and whether he or she is legally trained. Turning to structural factors, conventional wisdom suggests that administrative boards rather than governors are better positioned to buck public opinion and, therefore, more likely to grant clemency petitions. ${ }^{\$ S}$ The potential also exists for the variable clusters to interact. For example, political factors are more likely to have an

\footnotetext{
${ }^{* 4}$ See, e.g., Sisk, supra note 10, at 14-18 (discussing the controversial pardons authorized by former President Clinton); Babington, supra note 65 (same); Lichtblau, supra note 65 (same).

See William Claiborne, Ill. Governor, Citing Errors, Will Block Executions, Wash. Post, Jan. 31, 2000, at A1 (describing Governor Ryan's moratorium on executions); Alexia Elejalde-Ruiz, Illinois Governor Empties Death Row: Labels State's System a 'Catastrophic Failure,' Boston Globe, Jan. 12, 2003, at A1 (reporting Governor Ryan's blanket clemency grant to all death row inmates); Christi Parsons \& Jeff Coen, Panelists, not Ryan Puppets: Clemency Review Board Speaks Its Own Mind, Chi. Trib., Oct. 20, 2002, §1, at 15 (describing Illinois's clemency review board).

${ }^{*}$ Recognizing its potential importance, Professor Pridemore calls for research that compares states where "the governor alone makes the final [clemency] decision" with states where an administrative board or a blend of the executive and administrative models makes the clemency decision. Pridemore, supra note 36 , at 178 n.15.

${ }^{57}$ See Kobil, supra note 7, at 571.

see, e.g., Paul Whitlock Cobb, Jr., Note, Reviving Mercy in the Structure of Capital Punishment, 99 Yale L.J. 389, 407 (1989) (arguing that clemency authority should be vested in administrative boards to better insulate clemency decisions from political pressures and ensure greater consideration of mercy); see also sources cited supra note 82 .
} 
effect in states that vest clemency authority in elected governors rather than appointed administrative boards. Attention to the influence of political or structural variables on clemency decisions thus far has been largely anecdotal. Consequently, like so much in legal scholarship, debates about what factors influence clemency decisions within the death penalty context often take place without the benefit of data. ${ }^{89}$

\section{METHODOLOGY AND DATA}

\section{A. Methodology}

My research methodology pivots on a comparison between two groups of defendants: those put to death and those removed from death row through clemency. The dependent variable, COMMUTE, is a dummy variable coded for " 1 " if a defendant's clemency petition was granted and " 0 " if the petition was denied..$^{90}$ I consider an array of factors that plausibly could influence whether a death row inmate receives clemency. I organize these explanatory factors into three clusters of independent variables: (1) defendant characteristics, (2) political factors, and (3) structural factors.

My general clemency model predicts that the probability of a defendant receiving clemency depends on three clusters comprised of twenty-one independent variables. ${ }^{91}$ Multivariate logistic regression

\footnotetext{
${ }^{89}$ Ironically, the death penalty is one area within legal scholarship that benefits from comparatively more, as well as more sophisticated, empirical study. At the risk of offending those not mentioned, see Liebman et al., supra note 21; Baldus et al., supra note 21; Eisenberg et al., Forecasting Life and Death, supra note 22. A recent law review symposium covered the topic as well. See Symposium: How the Death Penalty Works: Empirical Studies of the Modern Capital Sentencing System, 83 Cornell L. Rev. 1431 (1998).

${ }^{90}$ A dummy variable is coded " 1 " when the characteristic of interest is present and " 0 " when it is not. For a helpful discussion about the use of dummy variables in regression models, see Melissa A. Hardy, Regression with Dummy Variables (Sage Univ. Papers, Quantitative Applications in the Social Sciences Series No. 07-093, 1993).

${ }^{91}$ The variables do not have multicollinearity problems. For a general discussion of multicollinearity, see William D. Berry, Understanding Regression Assumptions (Sage Univ. Papers, Quantitative Applications in the Social Sciences Series No. 07092, 1993). Also, the maximum variance inflation score ("VIF") for any of the independent variables is 1.44 . (The VIF scores were derived from SPSS multiple regression rather than the logistic regression command.) This is well below 5.00 , the value that most conservative statisticians use to detect problems associated with multicollinearity. See David Jacobs \& Jason T. Carmichael, The Political Sociology of the
} 
allowed me to analyze the discrete influence of these independent variables. Logistical regression was appropriate given the dichotomous dependent variable. ${ }^{92}$

\section{B. Data}

With data, we can develop and test important hypotheses related to the influence of three clusters of variables-defendant charac-

Death Penalty: A Pooled Time-Series Analysis, 67 Am. Soc. Rev. 109, 121-22 n.12 (2002); see also John Fox, Regression Diagnostics 10-13, 12 tbl.3.1 (Sage Univ. Papers, Quantitative Applications in the Social Sciences Series No. 07-079, 1991) (arguing that VIF scores need to exceed anywhere from 5.0 to 10.0 before much damage is done to the precision of the estimate by multicollinearity).

${ }^{52}$ The selection of logistic regression warrants discussion. Because the dependent variable-COMMUTE-is dichotomous (coded either " 1 " or " 0 "), the usual linear regression models, such as Ordinary Least Squares ("OLS"), are not appropriate. For example, OLS models allow the predicted values of the dependent variable to fall outside of the 0 to 1 range. Moreover, OLS is relatively less efficient because the error cannot normally distribute or vary constantly. For a more complete discussion of these points, see Michael O. Finkelstein \& Bruce Levin, Statistics for Lawyers 458-72 (2d ed. 2001); John Fox, Applied Regression Analysis, Linear Models, and Related Methods 442 (1997).

In contrast to OLS models, logit and probit models are well suited to analyze dichotomous dependent variables. I settled on a logit model for two main reasons. First, logit models are easier to use and interpret. See id. at 444-46. Second, the weight of the empirical literature favors logit models. See Theodore Eisenberg \& Sheri Lynn Johnson, The Effects of Intent: Do We Know How Legal Standards Work?, 76 Cornell L. Rev. 1151, 1185 n.155 (1991); Vicki Schultz \& Stephen Petterson, Race, Gender, Work, and Choice: An Empirical Study of the Lack of Interest Defense in Title VII Cases Challenging Job Segregation, 59 U. Chi. L. Rev. 1073, 1121 n.129 (1992).

In logistic regression, the dependent variable is the natural log of the ratio comprised of the probability that an event occurs divided by the probability that it does not: $\mathrm{L}=\ln [\mathrm{p} /(1-\mathrm{p})]$. For more on logistic regression models, see generally John $\mathrm{H}$. Aldrich \& Forrest D. Nelson, Linear Probability, Logit, and Probit Models (Sage Univ. Papers, Quantitative Applications in the Social Sciences Series No. 07-045, 1984) (deriving equations for logit and probit models); Alfred DeMaris, Logit Modeling: Practical Applications (Sage Univ. Papers, Quantitative Applications in the Social Sciences Paper No. 07-086, 1992) (describing use and application of logit models); Eric A. Hanushek \& John E. Jackson, Statistical Methods for Social Scientists 179-216 (1977) (explaining the discrete variable problem and deriving logit and probit models). Although both logit and probit models transform the actual proportion responding on the independent variables, probit models do so by replacing the observed proportions with the value of the standard normal curve below which the observed proportion of the area is located. Finally, the model assumes that the cases are independent both across and within groups. This assumption holds so long as, for example, there is no within-state effect present. The possibility of a within-state effect or, more germane to death penalty research, variations among counties within a state, warrants further scholarly attention. 
teristics, political factors, and structural factors-on states' decisions to grant clemency. ${ }^{93}$ A comparison of defendants who were executed and those who were not reveals whether these two subgroups vary in important ways.

\section{Defendant Characteristics}

The Bureau of Justice Statistics ("BJS") gathers data on every individual who is, or has been, under a sentence of death in the United States since 1973. ${ }^{94}$ The available data are current through 1999, inclusive, and contain 7,416 observations. ${ }^{95}$ The BJS data come from the prisons, which gather data under the National Prisoner Statistics Program. These data contain an array of background characteristics on all those sentenced to death as well as information about how defendants were removed. ${ }^{96}$

Because of differences between federal and state clemency procedures, I excluded the small number of defendants convicted of federal crimes and sentenced to death $(\mathrm{N}=21)$, as well as those who received death sentences in the District of Columbia $(\mathrm{N}=3) \cdot{ }^{97} \mathrm{~A}$ more important restriction is our focus on two discrete (though related) defendant subgroups: those executed by a state $(\mathrm{N}=598)$ and those removed from death row through clemency $(\mathrm{N}=178) .{ }^{98}$ These

${ }^{93}$ This study does not consider what happens to the defendant following a grant of executive clemency. For example, this analysis does not distinguish between defendants serving life sentences without the possibility of parole and those released from custody.

${ }^{94}$ See BJS, supra note 39.

${ }^{95}$ A single defendant may generate more than one observation in the BJS dataset. This could happen if an individual were sentenced to death, removed from death row, and then reentered after a related legal proceeding or, perhaps, by a subsequent conviction and death sentence. The number of such defendants is likely to be small, however.

${ }^{96}$ Regrettably, the dataset does not include information on two salient aspects: race of the victim and whether the murder involved "intimates" (that is, took place within the domestic sphere). The former point obscures assessments about the potential influence of race; the latter of gender. See infra Section IV.A.

${ }^{97}$ For a thorough discussion of the federal death penalty, see Rory $\mathrm{K}$. Little, The Future of the Federal Death Penalty, 26 Ohio N.U. L. Rev. 529 (2000).

${ }^{98}$ These adjustments were necessary because defendants can be "removed" from death row in other ways. For example, a defendant can die of natural causes prior to a scheduled execution. Also, a capital sentence can be overturned or declared unconstitutional. Non-clemency reasons for removal fall outside the scope of this study, however. 
data restrictions reduced the relevant BJS data to 776 observations. $^{99}$

\section{Political Factors}

I supplemented the BJS dataset with additional political variables, including information on each governor's gender, age, political party, religion, and education. ${ }^{100}$ In addition, the variable

Some ambiguity exists, however, in the manner in which various states construe the term "clemency." Although separate coding exists that is designed to capture removals caused by changes in state or federal law, some states may have resorted to clemency in instances where state officials perceived legal uncertainty (as opposed to instances when clemency is granted for humanitarian reasons). In addition, in some states, judges might exercise something resembling executive clemency authority. If so, this ambiguity might inflate clemency levels. For a detailed description of clemency grants limited to traditional humanitarian reasons, see Death Penalty Information Center, Commutations in Capital Cases on Humanitarian Grounds, at http://www.deathpenaltyinfo.org/clemency.html (last visited Oct. 26, 2002) (on file with the Virginia Law Review Association).

"It is important to note that the final disposition of a significant number of death row inmates is not yet known. On the final date of the reporting period covered by these data (December 31, 1999), 3,527 defendants remained on death row. My decision to exclude those presently on death row (that is, inmates who have neither been executed nor been granted clemency) warrants comment. Put simply, for almost all of those presently on death row a clemency decision has not been reached. Clemency petitions typically follow the legal appeals process and are the final step prior to execution. Including individuals presently on death row or those removed from death row because of changes in the law, successful appeals, or death from causes other than execution would increase the number of potential outcomes. By focusing my study on individuals where the outcome of interest-the disposition of a clemency petition-is known, I substantially reduce the modeling difficulties that flow from multiple outcomes. Such difficulties limit other studies. See, e.g., Liebman et al., supra note 21, at 26-27 (chronicling and discussing difficulties in data collection for post-conviction outcomes); Eisenberg et al., Deadly Paradox, supra note 22 (describing anomalies arising from whether the state law permits a defendant to be sentenced to life in prison without parole). The reduction of modeling complexities does not come without complications, though. My exclusion introduces the possibility of selection bias. On balance, however, the benefits flowing from reducing modeling complexity and working with known outcomes outweigh the potential costs of selection bias in this context.

${ }^{10}$ Information for these supplemental variables derives mainly from the standard, published, biographical sources. See, e.g., Marie Marmo Mullaney, Biographical Directory of the Governors of the United States 1988-1994 (1994) (providing a biographical sketch of governors from all fifty states). I considered other standard background variables, such as a governor's race and ethnic origin, but ultimately omitted them from this analysis because there was not sufficient variation to warrant their inclusion. In any event, unreported supplemental runs reveal that their exclusion did not disrupt the results. 
PRESIDENT ELEC YEAR indicates whether a removal from death row took place during a presidential election year. Similarly, GOVERNOR ELEC YEAR identifies removals that took place between January and October during a gubernatorial election year in that state. ${ }^{101}$ EXIT CLEMENCY indicates whether clemency was granted during the month of December or January prior to the end of a governor's term. ${ }^{102}$ Thus, through EXIT CLEMENCY, I was able to consider the possible impact of "eleventh-hour pardons." ${ }^{103} \mathrm{Fi}$ nally, ELECT. ST. JUDGES signals whether clemency was granted in a state where the highest state court judges are elected.

\section{Structural Factors}

A final cluster of supplemental variables relates to structural factors. I collapsed the five forms of state clemency decisionmaking authority into three basic models: pure executive, pure administrative, and blended. ${ }^{104}$ PURE EXECUTIVE and Pure ADMINISTRATIVE signal those states that have granted sole clemency authority to ei-

${ }^{101}$ The BJS dataset specifies the month and year for each defendant removal, but not the day. Consequently, I cannot tell whether the removals took place before or after the various states' gubernatorial elections, all of which followed the national schedule of November elections. See Pridemore, supra note 36, at 169. Consequently, to be prudent, I coded GOVERNOR ELEC YEAR only for removals occurring during an election year from January 1 through October 31.

${ }^{102}$ Again, the BJS data provide information on the month and year of each removal from death row, but not the specific day. To be safe, I coded EXIT CLEMENCY as "1" only when the clemency was granted in a month following the month of a new governor's election and prior to the month of the ex-governor's relinquishment of authority.

${ }^{103}$ The issue of "eleventh-hour pardons" has arisen in the death penalty setting. In 1986, New Mexico Governor Toney Anaya granted clemency to five death row inmates. Similarly, Ohio Governor Richard Celeste granted clemency to eight death row inmates (including four female inmates) prior to leaving office in 1991. See Pridemore, supra note 36, at 168 n.7. (Former Illinois Governor Jim Ryan's recent emptying out of Illinois's death row during his final days as governor took place outside of my study's time-frame. See infra note 204 and accompanying text.) At the federal level, former President Clinton's use of executive clemency during the final days of his administration ignited controversy. See McPhie, supra note 65, at 538; Sisk, supra note 10, at 14-16.

${ }^{104}$ The coding flows from data presented in Table 1 . See supra Table 1; see also Death Penalty Information Center, Clemency Process By State, at http://www.deathpenaltyinfo.org/clemency.html (last visited October 26, 2002) (on file with the Virginia Law Review Association) (classifying states into one of the five models). 
ther the governor or an administrative board, respectively. ${ }^{105}$ State clemency decisionmaking authority that is neither purely executive nor purely administrative in design was coded as BLENDED and served as the reference group. Additionally, SOUTH and POST-1984 are dummy variables included in the BJS dataset and designed to control for potential variation flowing from regionality and time.

Table 2 summarizes descriptive statistics including the mean and the standard deviation for each variable. Although the analyses reported in Table 2 are merely descriptive, $I$ have nonetheless noted when the differences between the means for the group that was granted clemency and the group that was executed achieved statistical significance.

\footnotetext{
${ }^{105}$ Each state's clemency decisionmaking authority falls into one of three models. To test the effect of each model, two of the models are represented as dummy variables, while the third is a reference group. For a discussion of reference group selection, see Hardy, supra note 90, at 9-12. I selected the blended model as the reference group. Thus, it does not appear as an independent variable in the regression results. The blended group was a particularly attractive and logical reference group because I was most interested in the possible influence of the two models that generate the clearest contrast-the pure executive and administrative models. Moreover, unreported supplemental runs reveal that the selection of the blended group as the reference did not distort the results.
} 
Table 2: Descriptive Statistics (Mean and Standard Deviation) ${ }^{106}$

\begin{tabular}{|l|c||c||c|}
\hline & Executed & $\begin{array}{c}\text { Granted } \\
\text { Clemency }\end{array}$ & Sig. \\
\hline \hline Defendant: & & & \\
AFRICAN-AMERICAN & $.36(.48)$ & $.38(.49)$ & \\
HISPANIC & $.07(.26)$ & $.09(.29)$ & \\
OTHER & $.02(.13)$ & $.02(.13)$ & $* *$ \\
FEMALE & $.01(.07)$ & $.06(.23)$ & $* *$ \\
AGE & $39.69(8.25)$ & $32.86(9.39)$ & $* *$ \\
EDUCATION & $10.57(2.00)$ & $10.04(1.81)$ & $*$ \\
MARRIED & $.32(.47)$ & $.37(.48)$ & $* *$ \\
PRIOR FELONY & $.70(.46)$ & $.38(.49)$ & \\
& & & \\
Political: & $.14(.35)$ & $.16(.37)$ & \\
PRESIDENT ELEC YEAR & $.22(.41)$ & $.17(.38)$ & \\
GOVERNOR ELEC YEAR & $.57(.50)$ & $.54(.50)$ & \\
ELECTED STATE & & & \\
JUDGES & $.48(.50)$ & $.63(.48)$ & $*$ \\
DEMOCRATIC GOV & $.13(.33)$ & $.14(.35)$ & \\
CATHOLIC GOV & $.10(.30)$ & $.01(.11)$ & $*$ \\
FEMALE GOV & $54.21(7.68)$ & $52.56(9.70)$ & $*$ \\
GOVERNOR'S AGE & $.48(.50)$ & $.69(1.02)$ & $*$ \\
LAWYER GOV & $.00(.00)$ & $.10(.29)$ & $*$ \\
EXIT CLEMENCY & & & \\
& & & \\
Structural: & $.25(.43)$ & $.26(.44)$ & \\
PURE EXECUTIVE & $.04(.20)$ & $.06(.23)$ & $*$ \\
PURE ADMINISTRATIVE & $.95(.23)$ & $.41(.49)$ & $*$ \\
POST-1984 & $.72(.45)$ & $.62(.49)$ & $*$ \\
SOUTH & 598 & 178 & \\
N (valid list.) & & & \\
\hline
\end{tabular}

Note: $* \mathrm{p}<.05 ; * * \mathrm{p}<.01$.

${ }^{106}$ A standard T-test was used to determine whether differences between the two groups' means achieved statistical significance. 


\section{Data Limitations}

One limitation on the data used in this study flows from the absence of information on whether those put to death sought clemency prior to their execution. By definition, defendants that received clemency petitioned for it or, at the very least, were aware of clemency as an option. ${ }^{107}$ Consequently, the potential that bias might exist because of a selection effect lurks in the background. Despite the absence of information on this point, it is reasonable to assume that clemency was an option for those executed for several reasons, and thus the threat of bias from a selection effect is marginal.

First, it is difficult to imagine a defendant staring at death who would not pursue all avenues of judicial and extrajudicial relief. Overwhelming anecdotal evidence suggests that in most instances death row inmates pursue clemency as a matter of course. ${ }^{108}$ To be sure, a small number of defendants decline to pursue clemency once sentenced to death; most recently, Timothy McVeigh famously instructed his attorneys not to pursue the full range of appeals options-including clemency-that were available to him. ${ }^{109}$ The notoriety surrounding these extreme examples supplies indirect evidence of their scarcity, however. ${ }^{110}$

Second, even when a defendant declines to pursue clemency, others may pursue it for him. In some states third parties may intervene on behalf of a defendant and initiate the clemency process. In Illinois in the 1990s, for example, Guinevere Garcia, a Hispanic woman sentenced to death for murdering her husband, decided she

${ }^{107}$ In some cases, a third party may have sought clemency. See infra notes $108-09$ and accompanying text. Regardless of the precise impetus for clemency, the more important point is that defendants who received clemency were aware of it as an option.

${ }^{103}$ See Deborah Leavy, A Matter of Life and Death: Due Process Protection in Capital Clemency Proceedings, 90 Yale L.J. 889, 896 (1981).

${ }^{10}$ Because McVeigh was convicted of a federal crime, only President Bush possessed the executive authority to grant clemency.

${ }^{110}$ See Howard Pankratz, McVeigh Decides not to Request Clemency, Denv. Post, Feb. 16, 2001, at A15. Stephen Spurr determined that in fifty-eight executions out of the 885 total executions conducted between 1960 and 2001 the individual executed "volunteered" or abandoned his right to contest his capital judgment at some stage in the litigation. These numbers translate to a rate of approximately $6.6 \%$. See Stephen J. Spurr, The Future of Capital Punishment: Determinants of the Time from Death Sentence to Execution, 22 Int'l Rev. L. \& Econ. 1, 3 n.11 \& tbl.1 (2002). 
would not seek clemency from Illinois Governor Edgar. ${ }^{111}$ Nevertheless, celebrity Bianca Jagger became aware of Ms. Garcia's case and, over her objection, petitioned Governor Edgar for clemency on her behalf. Because clemency is an act of "grace" on behalf of a state, formal acceptance by the recipient is not necessary for clemency to become effective. Ms. Jagger's clemency petition succeeded and Ms. Garcia was removed from death row. ${ }^{112}$

Third, even when a defendant declines to pursue clemency and no third party seeks to apply on a defendant's behalf, governors vested with clemency authority can exercise that authority broadly. Given the political implications that invariably flow from the death penalty, carrying out an execution is not a task that most governors undertake lightly. ${ }^{113}$ Moreover, recent trends notwithstanding, ${ }^{114}$ state-enforced executions are rare events and, partly as a consequence, generate meaningful levels of media interest and coverage. For all of these reasons, it is highly unlikely that a governor would carry out a death sentence without engaging in his or her own independent review of a case, however cursory such a review might be. Indeed, at least one state, Ohio, statutorily requires that the governor receive a clemency recommendation before the state carries out an execution, regardless of a defendant's wishes. ${ }^{115}$

${ }^{111}$ Bianca Jagger, Death Penalty Cases and the Lack of Meaningful Appellate Review in Commutation Proceedings, 28 Cap. U. L. Rev. 585, 585 (2000).

${ }^{112}$ Interestingly, Illinois changed its law subsequent to the Bianca Jagger intervention so that third parties cannot file clemency applications without the inmate's permission. See 730 Ill. Comp. Stat. Ann. 5/3-3-13(c) (West 1997) ("Application for executive clemency under this Section may not be commenced on behalf of a person who has been sentenced to death without the written consent of the defendant, unless the defendant, because of a mental or physical condition, is incapable of asserting his or her own claim.").

${ }^{113}$ Former California Governor Edmund "Pat" Brown described executive clemency as an "awesome, ultimate power over the lives of others." Edmund G. (Pat) Brown \& Dick Adler, Public Justice, Private Mercy: A Governor's Education on Death Row 163 (1989).

${ }^{114}$ See supra Figure 2.

${ }^{115}$ Ohio has enacted a three-step process that ensures consideration of clemency. First, a mandatory clemency hearing is scheduled forty-five days prior to an execution date. Second, a death row inmate must be given notice of the right to meet with the clemency review board. Finally, the clemency review board must provide the governor with a clemency recommendation. See Michele K. McGuire, Casenotes, Ohio Adult Parole Authority v. Woodward, 118 S. Ct. 1244 (1998), 9 Seton Hall Const. L.J. 1069, 1078 (1999). 
The incentive structure for defendants, interested third-party intervenors, and governors thus makes the reasonable assumption that those executed were aware of and pursued clemency options. While possible exceptions to this assumption surely exist, their number is likely extremely small and, therefore, poses little threat to the integrity of the data. In short, the potential threat to the data posed by a selection effect is minimal.

An additional limitation on the data I have relied upon flows from three necessary assumptions. One is that the quality of clemency petitions is uniform among petitioners and over time. While I am quite comfortable with the assumption that the overwhelming majority of defendants sentenced to death petition for clemency, I am less comfortable with the assumption that clemency petitions are of uniform quality. ${ }^{116}$ Unfortunately, no data exist that permit a meaningful assessment of clemency petition quality.

A second, related assumption involves the underlying factual circumstances surrounding each clemency petition. Again, the data do not permit an assessment of factual differences that might make one clemency petition more successful than another and, as a result, my model assumes no variation. Although this is a clear data limitation that makes my model less than complete, it does not substantially degrade the results. First, even without these data, the results contribute to the research base. It remains interesting to know, for example, whether defendant characteristics, political variables, or structural factors influence clemency decisions notwithstanding factual differences among clemency petitions. Second, although some capital offenses are certainly more heinous than others, this study's focus on only those charged with, and convicted of, a capital offense and sentenced to death substantially limits the degree of possible variation.

A third assumption is that states' clemency decision mechanisms remained static throughout the period of the study. While state leg-

${ }^{116}$ The quality of a defendant's clemency petition is frequently a function of the quality of the defendant's representation. With respect to the latter, it is widely acknowledged that quality variations exist and that in some instances the variations are tremendous. See, e.g., Stephen B. Bright \& Patrick J. Keenan, Judges and the Politics of Death: Deciding Between the Bill of Rights and the Next Election in Capital Cases, 75 B.U. L. Rev. 759, 800-03 (1995) (noting that decisions in capital cases increasingly have become campaign fodder in both judicial and non-judicial elections). 
islatures no doubt adjusted some aspects of their death penalty statutes during this twenty-seven year period, much of the activity focused on due process concerns raised by the Supreme Court's Furman decision. ${ }^{117}$ Moreover, provisions for clemency are moored in many state constitutions, ${ }^{118}$ thereby reducing the likelihood of frequent tinkering. It therefore remains reasonable to assume that the application of state clemency structures in 1999 to clemency decisions made in earlier years did not materially distort the results even if this assumption is not accurate in every instance.

A final limitation flows from missing data on three independent variables. Although the data used in this study draw partly from the nation's largest and leading dataset on clemency in the death row context, three independent variables of interest-PRIOR FELONY, MARRIED, and EDUCATION-have missing data, although missing data are not substantial for any of the variables. ${ }^{119}$ To salvage as many cases as possible for the regression analyses, I handled missing data for each variable as follows. Where a defendant's educational attainment is missing, I have replaced the missing value with that variable's mean. For prior felony convictions and marital status-both dummy variables-I treat each case with missing data as not possessing the characteristic of interest. This approach has the effect of exerting downward bias on the variable's influence.

As an additional check, I re-ran all models with three additional dummy variables each signaling whether a particular case contains missing data for any of the three variables. In so doing, I was able to determine whether those few cases with missing data systematically differed from those that possessed complete data panels. The inclusion of two of these dummy variables-EDUCATION and

${ }^{117}$ For a discussion, see infra notes $244-46$ and accompanying text. Also, one discernable period of time during which some states changed their clemency decisionmaking structures was the first half of the twentieth century, well before the time period of this study. For a discussion, see Elkan Abramowitz \& David Paget, Note, Executive Clemency in Capital Cases, 39 N.Y.U. L. Rev. 136, 141 (1964).

${ }^{118}$ See supra note 70.

${ }^{119}$ For example, data on defendants' education attainment levels are available in $92.1 \%$ of the cases. 
MARRIED-did not substantially affect the results. ${ }^{120}$ Cases with missing PRIOR FELONY data did systematically differ from cases not missing these data. Thus, all models presented are run once with and once without the PRIOR FELONY variable. A comparison between Columns (A) and (B) in Tables 3 and 4 illustrates that the inclusion of the PRIOR FELONY variable did not destabilize the results.

\section{RESULTS AND DISCUSSION}

Table 3 presents results from three versions of the full model of death row inmates removed through clemency. The first column of results (A) reflects the standard model. The middle column (B) is the standard model less the PRIOR FELONY variable. ${ }^{121}$ The final variation of the full model, presented in Column (C), reflects yet another important wrinkle. Specifically, the literature notes the legal uncertainty of the death penalty until $1985 .^{122}$ To accommodate any potential distorting influence, Column (C) presents results from the standard run for death row removals that took place after 1984. A comparison of Columns (A), (B), and (C) illustrates that the results remain remarkably stable and robust across all three variants of the full model.

\footnotetext{
${ }^{120}$ For the sake of thoroughness, I also ran the general model with the three independent variables as well as a dummy variable indicating the presence of missing data. Again, these alternative runs did not undermine the overall results.

${ }^{21}$ As previously discussed, one cannot safely assume that missing data for the PRIOR FELONY variable are randomly distributed. See supra notes 119-20 and accompanying text.

${ }^{122}$ Professors Blume and Eisenberg note the "effects of early twists and turns in the post-Furman death penalty era" and accordingly limited their use of the BJS dataset to those defendants sentenced after 1984. See Blume \& Eisenberg, supra note 38, at 479 \& n. 52,480 \& n.53.
} 
Table 3: Death Row Removals Through Clemency (1=yes) ${ }^{123}$

\begin{tabular}{|c|c|c|c|}
\hline & $\begin{array}{c}\text { Standard } \\
\text { Model }\end{array}$ & $\begin{array}{c}\text { Standard Model } \\
\text { Without Prior } \\
\text { Felony }\end{array}$ & $\begin{array}{c}\text { Standard Model } \\
\text { for Post-1984 } \\
\text { Cases } \\
\end{array}$ \\
\hline \multicolumn{4}{|l|}{ Defendant: } \\
\hline AFRICAN-AMERICAN & $.13(.27)$ & $.09(.27)$ & $.07(.33)$ \\
\hline HISPANIC & $.59(.45)$ & $.63(.45)$ & $.46(.53)$ \\
\hline OTHER & $.05(.95)$ & $.39(.93)$ & $.60(.93)$ \\
\hline FEMALE & $2.04 *(.98)$ & $2.08 *(.96)$ & $2.87 * *(1.06)$ \\
\hline AGE & $-.07 * *(.02)$ & $-.08 * *(.02)$ & $-.05 *(.02)$ \\
\hline EDUCATION & $-.24 * *(.07)$ & $-.23 * *(.07)$ & $-.27 * *(.08)$ \\
\hline MARRIED & $.38(.27)$ & $.42(.27)$ & $.36(.32)$ \\
\hline PRIOR FELONY & $-.81 * *(.26)$ & 一 & $-.24(.32)$ \\
\hline \multicolumn{4}{|l|}{ Political: } \\
\hline PRESIDENT EleC YeAR & $-.42(.35)$ & $-.44(.35)$ & $.43(.42)$ \\
\hline GOVERNOR ELEC YEAR & $.25(.32)$ & $.33(.31)$ & $-.00(.37)$ \\
\hline ELECTED STATE JUDGES & $.40(.30)$ & $.37(.29)$ & $.67(.38)$ \\
\hline DEMOCRATIC GOV & $-.38(.29)$ & $-.37(.29)$ & $-.30(.35)$ \\
\hline CATHOLIC GOV & $-.37(.40)$ & $-.38(.40)$ & $-.49(.60)$ \\
\hline FEMALE GOV & $-.77(.79)$ & $-.77(.79)$ & $-.81(.80)$ \\
\hline GOVERNOR'S AGE & $.02(.02)$ & $.02(.02)$ & $.02(.02)$ \\
\hline LAWYER GOV & $.16(.18)$ & $.18(.19)$ & $.27(.29)$ \\
\hline EXIT CLEMENCY & $9.00(12.85)$ & $9.03(12.96)$ & $9.54(15.02)$ \\
\hline \multicolumn{4}{|l|}{ Structural: } \\
\hline PURE EXECUTIVE & $.57(.34)$ & $.37(.34)$ & $.40(.47)$ \\
\hline PURE ADMINISTRATIVE & $1.30 *(.57)$ & $1.28 *(.57)$ & $1.73 * *(.60)$ \\
\hline PosT-1984 & $-3.61 * *(.33)$ & $-3.70 * *(.33)$ & - \\
\hline SOUTH & $-1.34 * *(.32)$ & $-1.30 * *(.32)$ & $-1.04 *(.40)$ \\
\hline constant & $6.12 * *(1.33)$ & $6.21 * *(1.33)$ & $1.02(1.52)$ \\
\hline$\%$ predicted & 90.1 & 89.6 & 91.5 \\
\hline pseudo $\mathrm{R}^{2}$ & .39 & .38 & .17 \\
\hline $\mathrm{N}$ (valid list.) & 776 & 776 & 639 \\
\hline
\end{tabular}

Note: $* \mathrm{p}<.05 ; * \mathrm{p}<.01$

${ }^{123}$ Table 3 reports regression coefficients and standard errors (in parentheses). A fourth, unreported run involves the standard model for post-1984 without the PRIOR FELONY variable. Results from this alternative are generally consistent with the three reported runs. 


\section{A. Defendant Variables}

Gender. Gender has long been assumed to play a role in capital punishment. ${ }^{24}$ Ample qualitative research illustrates that women are far less likely to receive a death sentence, ${ }^{125}$ and those women sentenced to death are almost never executed. ${ }^{126}$ Differences in the types of homicides that male and female defendants commit play a substantial role in explaining differences in punishment. In contrast to their male counterparts, women who murder are far more likely to kill those known and intimate to them, principally within the domestic sphere. ${ }^{127}$ A predatory murder of a stranger is considered an aggravating factor that enhances the possibility of a death sentence; murder within the context of domestic violence is not. ${ }^{128}$ Others note that women are less likely to receive death sentences even when they commit acts for which comparable male defendants receive death sentences. ${ }^{129}$ The fact that women are more likely than their male counterparts to receive clemency fuels perceptions that women's favored status within the death row context

\footnotetext{
${ }^{124}$ See Blume \& Eisenberg, supra note 38, at 494 tbl.5, 497 tbl.7 (finding that male defendants eligible for the death penalty are more likely than female defendants eligible for the death penalty to be placed on death row and that, once on death row, male defendants have more difficulty getting off death row through various mechanisms); Elizabeth Rapaport, Equality of the Damned: The Execution of Women on the Cusp of the $21^{\text {st }}$ Century, 26 Ohio N.U. L. Rev. 581, 584 (2000) (concluding that men are statistically more likely to be put to death than women after holding germane background variables constant); Andrea Shapiro, Unequal Before the Law: Men, Women and the Death Penalty, 8 Am. U. J. Gender, Soc. Pol'y \& L. 427, 430-31 (2000) (same); Victor L. Streib, Gendering the Death Penalty: Countering Sex Bias in a Masculine Sanctuary, 63 Ohio St. L.J. 433 (2002) (same); see also Furman v. Georgia, 408 U.S. 238, 365 (1972) (Marshall, J., concurring) ("There is also overwhelming evidence that the death penalty is employed against men and not women.").

${ }^{125}$ See Rapaport, supra note 124 , at 584; Shapiro, supra note 124 , at $430-31$.

${ }^{126}$ See Streib, supra note 124, at 434.

${ }^{127}$ See Amy E. Pope, A Feminist Look at the Death Penalty, 65 Law \& Contemp. Probs., Winter 2002, at 257, 274; Elizabeth Rapaport, Capital Murder and the Domestic Discount: A Study of Capital Domestic Murder in the Post-Furman Era, 49 SMU L. Rev. 1507, 1517 (1996).

${ }^{128}$ See Rapaport, supra note 127 , at 1511-13.

${ }^{129}$ See Streib, supra note 124, at 435.
} 
extends through the clemency stage..$^{130}$ These perceptions have attracted considerable academic commentary. ${ }^{131}$

Although some suggest that structural gender bias within the criminal justice system makes women more attractive candidates for clemency, if they ever reach that stage, ${ }^{132}$ women's advantages at the clemency stage are counter-intuitive. On closer inspection, it is easier to envision circumstances that would make female defendants less likely to receive clemency. As previously noted, when women murder they typically do so in ways that differ from men. For example, women are far more likely to commit murders of passion, and they tend to kill principally within the domestic sphere. ${ }^{133}$ Although almost every capital offense involves a murder, not every murder receives a capital sentence. Because domestic violence murder typically does not constitute an aggravating factor, women defendants are less likely to receive a death sentence. ${ }^{134}$ It is precisely this sifting by prosecutors, judges, and juries as they sort through what types of murders warrant capital charges and a death sentence that allows gender stereotypes to manifest themselves and systematically protect women from the death penalty.

Given the degree of sifting that takes place prior to the clemency stage and the general tilt favoring leniency for women, however, those women sentenced to death are likely to have more aggravating factors than their male counterparts. ${ }^{135}$ In those rare instances in

${ }^{130}$ See Pridemore, supra note 36 , at 176 . Professor Pridemore correctly notes, however, that generalizations are difficult because of the relatively small number of women involved with capital punishment in general and clemency in particular. Id.

${ }^{131}$ For example, traditional feminist scholars have struggled mightily on this issue because it escapes easy explanation or justification. See, e.g., Victor L. Streib, Sentencing Women to Death, 16 Crim. Just. 24, 27-28 (2001) (noting the uncomfortable "dilemma"); see also Elizabeth Rapaport, The Death Penalty and Gender Discrimination, 25 Law \& Soc'y Rev. 367, 368 (1991) (remarking that “[a]t worst, [a feminist's complaint about gender discrimination] suggests a campaign to exterminate a few more wretched sisters").

${ }^{132}$ See, e.g., Pope, supra note 127 , at $276-77$ (noting the "male orientation" of the criminal justice system and arguing against capital punishment for "domestic violence killers").

${ }^{133}$ See supra note 127 and accompanying text.

${ }^{134}$ See, e.g., Pope, supra note 127 , at 274.

${ }^{135}$ At the very least, women who wind up on death row are functionally equivalent to their male counterparts. See Victor L. Streib, Death Penalty for Female Offenders, 58 U. Cin. L. Rev. 845, 878-79 (1990) (arguing that women sentenced to death possess many of the same qualities as male death row inmates). 
which a women murders within the domestic sphere and receives the death penalty, it usually involves such aggravating factors as "extreme brutality, commission during another felony, and multiple murders." 136 Thus, to the extent that culpability and aggravating factors inform clemency decisions, the few women who make it to death row should, in general, be weaker candidates for clemency.

As Table 3 illustrates, however, the opposite is true. The regression results comport with conventional wisdom and support the hypothesis that the clemency process is systematically biased in favor of women. Women are significantly more likely to receive clemency than men, even after controlling for an array of background factors. Simply put, one reason why women on death row are "almost never executed"137 is that they receive clemency at a disproportionate rate. These findings comport not only with death penalty findings but with prior clemency research as well. ${ }^{138}$

Ordinarily, one should be cautious in drawing firm conclusions from empirical results. ${ }^{139}$ Nonetheless, in light of the strong and robust findings from this study, their consistency with other empirical findings, ${ }^{140}$ and the overwhelming qualitative and anecdotal evidence illustrating how women's experience with clemency and death penalty processes differs from men's experience, ${ }^{141}$ it may be time to render at least a tentative verdict. Whether because of social norms or stereotypes, ${ }^{142}$ the "unusualness" of women sentenced

${ }^{126}$ Rapaport, supra note 127 , at 1515 tbl.1.

${ }^{137}$ See Streib, supra note 124 , at 469.

${ }^{123}$ See Pridemore, supra note 36 , at 176.

${ }^{139}$ One classic mistake is to infer substantive causation from statistical correlation.

${ }^{12}$ See Pridemore, supra note 36 , at 176.

${ }^{141}$ See supra note 124.

${ }^{142}$ See Chimene I. Keitner, Victim or Vamp?: Images of Violent Women in the Criminal Justice System, 11 Colum. J. Gender \& L. 38, 38 (2002) (arguing that an "uncritical resort to sex-role stereotypes" pervades the criminal justice system, including the death penalty); Elizabeth Rapaport, Some Questions About Gender and the Death Penalty, 20 Golden Gate U. L. Rev. 501, 503-04 (1990) (describing the "chivalry" theory's explanation for the influence of gender on the application of the death penalty). Concerns about women serving in combat roles also provide a possible analogy and reflect this general point. See Col. Fred L. Borch, III, Camouflage Isn't Only for Combat: Gender, Sexuality, and Women in the Military-Battle Cries and Lullabies: Women in War From Prehistory to Present, 164 Mil. L. Rev. 235 (2000) (book reviews); David B. Cruz, Disestablishing Sex and Gender, 90 Cal. L. Rev. 997, 1001 (2002) ("Many laws and government practices in the United States also treat males and females as fundamentally different types of creatures.") (citing Rostker $v$. 
to death, ${ }^{143}$ the different ways in which men and women murder, ${ }^{144}$ or a consistent run of extraordinary "good luck" that defies standard mathematical probabilities, the weight of existing evidence demonstrates that male and female death row inmates receive different treatment when it comes to clemency grants.

Given the possible implications under the Equal Protection Clause ${ }^{145}$ gender's influence on clemency decisions troubles many, including feminists, because it suggests that gender-more specifically, gender stereotypes-continues to influence the criminal justice system. ${ }^{146}$ To be sure, results from this study alone would not provide the evidentiary foundation sufficient to prove a violation of the Equal Protection Clause. Rather, these results might spur litigants to examine more closely specific states' clemency processes and how these processes intersect, if at all, with gender. That gender preferences manifest in life-and-death decisions only increases the discomfort surrounding gender's influence on clemency decisions. ${ }^{147}$

Race and Ethnicity. Similar to gender, the influence of race and ethnicity on the application of the death penalty has long been assumed and is well documented. Many commentators, most recently Professor James Liebman, have explored the empirical disparities

Goldberg, 453 U.S. 57 (1981)); see also Schlesinger v. Ballard, 419 U.S. 498 (1975) (upholding the U.S. Navy's exclusion of women from certain combat flying positions).

${ }^{143}$ See Elizabeth Rapaport, Staying Alive: Executive Clemency, Equal Protection, and the Politics of Gender in Women's Capital Cases, 4 Buff. Crim. L. Rev. 967, 979 (2001) (arguing that women might enjoy the benefits flowing from "fast track" review which, includes greater scrutiny of their cases because of the small number of women on death row)[hereinafter Rapaport, Staying Alive]; Rapaport, supra note 124, at 585 (same).

${ }^{144}$ See Rapaport, supra note 127 , at 1517.

${ }^{145}$ See Rapaport, Staying Alive, supra note 143, at 968 ("Grants [of clemency] to women may appear to violate equal protection by according special treatment by reason of gender.").

${ }^{146}$ See, e.g., Pope, supra note 127 , at $274-75$.

${ }^{147}$ Some argue that the "benefit" that women receive at the clemency level should be afforded to men. See Larraine Schmall, Forgiving Guin Garcia: Women, the Death Penalty and Commutation, 11 Wis. Women's L.J. 283, 326 (1996). Others are bold enough to acknowledge the other logical-yet unpalatable-option: Decrease the clemency rate women now enjoy to the rate men experience. See generally Rapaport, supra note 131, at 368 (noting that efforts to confront the influence of gender on clemency decisions risk suggesting "a campaign to exterminate a few more wretched sisters"). 
of the death penalty's application. ${ }^{148}$ Research on who receives the death penalty has long reported the influence of race ${ }^{149}$ and, to a lesser extent, ethnicity.

Racial and ethnic effects are typically assessed as they relate to defendants and victims. The precise nature and contour of the effect that defendant and victim race and ethnicity have in the death penalty context are nuanced and elude definitive and easy explanations. With respect to the effect that defendant race and ethnicity have on death sentences, a General Accounting Office ("GAO") survey of the empirical literature reported mixed results. ${ }^{151}$ Findings that the race of the victim had an effect are comparatively more consistent and robust. The GAO survey concluded that although a race-of-victim effect was detected throughout the death penalty process, variations existed in the strength of the effect at different

${ }^{143}$ See, e.g., U.S. Gen. Accounting Office, Death Penalty Sentencing: Research Indicates Pattern of Racial Disparities (1990), reprinted in The Death Penalty in America: Current Controversies 268 (Hugo Adam Bedau ed., 4th ed. 1997) [hereinafter GAO Report]; James S. Liebman et al., A Broken System, Part II: Why There Is So Much Error in Capital Cases, and What Can Be Done About It 156 (2002) (showing a pattern of evidence indicating differential treatment by race) [hereinafter Liebman et al., A Broken System, Part II]; James S. Liebman et al., A Broken System. Part II: Why There Is So Much Error in Capital Cases, and What Can Be Done About It, End Notes 67 n.330 (2002) [hereinafter Liebman et al., A Broken System, Part II, End Notes]; Baldus et al., supra note 21, at 1658 n.61, 1660 n.69, 1742-45 (cataloging relevant studies involving race); Samuel R. Gross \& Robert Mauro, Patterns of Death: An Analysis of Racial Disparities in Capital Sentencing and Homicide Victimization, 37 Stan. L. Rev. 27, 38-49 (1984) (same). Indeed, Professor Blume and colleagues note that "race is a central factor in explaining death row populations." John Blume et al., Explaining Death Row's Population and Racial Composition 2, 22, 33 (May 27, 2002) (unpublished manuscript, on file with the Virginia Law Review Association) (noting the significance of the black defendant/white victim effect in explaining the racial makeup of death row); see also U.S. Dep't of Justice, The Federal Death Penalty System: A Statistical Survey (1988-2000), at 6 (2000) (reporting that $80 \%$ of the cases submitted by federal prosecutors for death penalty review in the past five years have involved racial minorities as defendants); Eisenberg et al., Forecasting Life and Death, supra note 22, at 295 n.75, 300-01 tbl.6 (finding that juror and not defendant race influences capital juror votes).

${ }^{149}$ See supra note 148 .

${ }^{159}$ See, e.g., Rory K. Little, Why a Federal Death Penalty Moratorium?, 33 Conn. L. Rev. 791, 808 n.115 (2001) (noting that 593 of the 734 individuals considered for the federal death penalty were ethnic minorities).

${ }^{151}$ See GAO Report, supra note 148 , at 6 . For a helpful analysis of the GAO Report, see Baldus et al., supra note 21, at 1658-62. 
stages. ${ }^{152}$ Moreover, because it is likely that defendant race and victim race effects interact, it is important, where possible, to disentangle the distinct effects. ${ }^{153}$ Indeed, in a noted study of the death penalty in Philadelphia, Professor David Baldus found a race-ofdefendant effect independent of a race-of-victim effect. ${ }^{154}$ That is,

${ }^{152}$ GAO Report, supra note 148, at 5-6; see also Liebman et al., A Broken System, Part II, supra note 148, at 157-59, 359-60 (finding that although conventional wisdom suggests that a victim's race may increase the probability of the imposition of a death sentence, a victim's race does not correlate with higher error rates in death verdicts); Liebman et al., A Broken System, Part II, End Notes, supra note 148, 112 n.754 (same); Blume et al., supra note 148, at 33 (finding that while a black defendant/white victim effect helps explain the racial makeup of death rows, this effect does not explain the size of death row populations).

${ }^{153}$ Baldus et al., supra note 21 , at 1690 n.132, 1693 ("Before one can interpret the race of defendant and race of victim as having independent (i.e., additive) influences on death-sentencing rates, one first needs to rule out the possibility that the two interact' with one another in a nonindependent (i.e., nonadditive) way.").

Indeed, the need to disentangle these two effects is particularly important for my clemency study because my dataset does not include victim race information. Thus, a comparison of my finding that defendant race did not influence clemency decisions to contrary findings regarding death sentences becomes more probative if a defendant racial effect at the death sentence stage exists independent of any possible victim race effect.

${ }^{154}$ Id. at 1694 n.132 ("Our conclusion is that at both key points in the Philadelphia system at which death sentences are actually imposed, the race of the victim and the race of the defendant have an influence that is generally independent of the race of the defendant or the race of the victim, as the case may be."). This admittedly subtle point is important for my study of clemency because my clemency dataset does not include information on victim race. But see id. app. B at 1742-45 (summarizing various studies with mixed findings on the independent influence of defendant race effects on death penalty outcomes). Notably, very few, if any, of the studies cited in appendix B approach the level of methodological rigor that aptly characterizes Professor Baldus's study of the death penalty in Philadelphia.

Defendant race and ethnicity have also been considered in other components of the death penalty context. Findings from Professor Liebman's recent major study of error in capital cases illustrate further the underlying subtleties. He found that although defendant race did not significantly influence death sentence reversal rates, see Liebman et al., A Broken System, Part II, supra note 148, at 158, defendant ethnicity did. Specifically, Professor Liebman found that defendants who were neither AfricanAmerican nor white received somewhat lower reversal rates, especially at the habeas stage. Id. at 158; see also Liebman et al., A Broken System, Part II, End Notes, supra note 148, at $68 \mathrm{n} .336$ ("The only racial disparity of any note suggested by Table 6 is for death verdicts imposed on defendants who are neither African-American nor white, which have a somewhat lower reversal rate, especially at the habeas stage."). Additional evidence comes from a major study of capital case juror votes where researchers did not find a defendant race effect. See Eisenberg et al., Forecasting Life and Death, supra note 22, at 295 n.75, 300-01 tbl.6. (Interestingly, the researchers did find a significant juror-race effect.). 
even after accounting for the influence of the victim's race, minority defendants were still more likely than their white counterparts to receive a death sentence.

Despite the absence of a clear consensus on how race and ethnicity might influence the death penalty processes, the cumulative weight of the research on the influence of race and ethnicity on decisions about who receives the death penalty fuels perceptions about similar influences at the clemency stage..$^{155}$ Although existing evidence is clear that race has an effect (however undefined) in the death penalty context generally, evidence on the influence of defendant race and ethnicity in the specific clemency context is unsettled and points in conflicting directions. ${ }^{156}$

Notably, results from my study do not reveal any link between a defendant's race or ethnicity and clemency decisions. Although my principal claim here is a negative one-the absence of a statistically significant defendant racial or ethnic effect-the death row context makes even a negative claim important. ${ }^{157} \mathrm{My}$ finding does not rule out the absence of other racial or ethnic influences on clemency decisions. For example, data limitations preclude more refined analyses that would include information on the race and ethnicity

${ }^{15 s}$ See, e.g., Pridemore, supra note 36, at 163-64 (identifying several "common themes" that typically inform popular perceptions about clemency).

${ }^{155}$ Id. at 175-76 (finding that race does not appear to influence clemency decisions). But see Legislative Council of Md., Report of the Legislative Council Committee on Capital Punishment (1962) (noting the influence of defendants' race on final case disposition); Ohio Legislative Serv. Comm'n, Capital Punishment, Staff Research Report No. 46 (1961) (same).

It is worth noting that the empirical studies of clemency that draw from a large, national dataset-like this study-do not find a defendant race or ethnicity pull. In contrast, the state-specific case studies note a racial effect. The conflicting findings might flow from differences in data and methodology.

${ }^{157}$ A further technical word of caution is warranted with respect to interpreting a statistically insignificant finding. The power of a statistical test is the likelihood of detecting an effect of a specific size at a specified significance level (here, the standard $p<.05$ level). If the test used is not very powerful, the likelihood of detecting a statistical effect is diminished. Thus, perfectly designed and executed studies may fail to detect socially important differences "simply because the sample sizes are too small to give the procedure enough power to detect the effect." Stanton A. Glantz, Primer of Biostatistics 183 (3d ed. 1992). Therefore, it is important to consider a test's power when one claims that no significant effect has been detected. Here, however, my sample size is large enough to reduce the potential that it accounts for the insignificant findings regarding defendant race. See also Blume \& Eisenberg, supra note 38, at 491 n.83 (noting the importance of a sufficiently powerful test). 
of the defendants' victims. ${ }^{158}$ Some studies suggest that the race of the defendant has an effect independent of the race of the victim, however. ${ }^{159}$ The absence of the effect of the defendant's race at the clemency stage thus contrasts with findings of defendant race influence at the death sentencing stage.

It is possible that race does not appear as a statistically significant variable because this study does not account for the severity of the capital crime. Among death row inmates, there is variation in the severity of the capital murder offenses and, perhaps because of earlier biases in the death penalty system, racial minorities may have committed systematically less severe capital offenses. If so, minorities would be stronger candidates for clemency, and we would expect them to have higher rates of clemency grants. As Table 3 indicates, however, racial and ethnic minorities were not more likely to receive clemency. Thus, statistically similar rates of clemency do not necessarily indicate that the clemency system is unbiased.

This argument rests precariously upon numerous assumptions, however, and it fits uneasily with the findings of a gender effect. One assumption is that the severity of capital murders varies to a discernable degree. ${ }^{160}$ Another assumption is that non-white death row inmates committed less severe capital murders but nonetheless managed to end up on death row. An empirical test of these assumptions is not possible because of data limitations, and this argument is unpersuasive in light of the finding of a gender effect despite the plausibility of similar assumptions. ${ }^{161}$ That is, if systematic variation among death row inmates along racial and ethnic lines exists in terms of severity, it is arguable that a similar variation exists along gender lines. ${ }^{162}$ The results in Table 3 reveal a gender effect despite the assumption that women on death row committed

\footnotetext{
${ }^{158}$ Recall that researchers have found that the race of the defendants' victims influences decisions to mete out capital sentences. See supra note 148 and accompanying text.

${ }^{159}$ See, e.g., supra note 154 .

${ }^{160}$ For examples of scaling capital offenses by severity, see Baldus et al., supra note 21, at 1711 tbl.11, 1712 tbl.12; Eisenberg et al., Forecasting Life and Death, supra note 22 , at $287-89$ \& tbl.2.

${ }^{161}$ See supra notes $135-36$ and accompanying text.

${ }^{162}$ Specifically, it is possible that female death row inmates systematically were convicted of more severe capital murders.
} 
more severe capital murders. No analogous effect for race or ethnicity was detected.

What might account for the pull of race and ethnicity at various stages in the death penalty process and the absence of a similar tug at the clemency stage? One explanation for this contrast is that, by the time of the clemency decision, the influence of race has already run its course. The pool of defendants for whom clemency is relevant is defined by prior decisions concerning who receives the death penalty. As many note, defendant, victim, and juror race help explain systematic differences in terms of which defendants are placed onto death row. ${ }^{163}$ Having already skewed the larger universe of death penalty-eligible defendants, race might have comparatively little room left to exert any more pull once a defendant arrives at the stage when a clemency petition is typically filed.

An alternative (or supplemental) explanation is that race and ethnicity still matter and exert influence, but do so in a manner that eludes statistical detection. For example, the growing sensitivity of governors and, to a lesser extent, administrative clemency boards to the racial and ethnic profile of individuals considered for clemency might mask a racial effect. The number of defendants who receive clemency is far smaller than the number of defendants who do not. ${ }^{164}$ Moreover, the high level of discretion that surrounds all clemency decisions-regardless of how a state structures these decisions-affords decisionmakers considerable room to inject racial and ethnic dimensions into their determinations. The media attention that typically accompanies clemency decisions no doubt enhances sensitivity and attention to racial and ethnic issues. A heightened sensitivity to racial and ethnic disparities in terms of who receives clemency might, therefore, generate a use of race and ethnicity designed to reduce disparities. Finally, as noted earlier, the absence of victim race data might prevent detection of an important, though distinct, racial effect. Although victim race influences prosecutorial and sentencing decisions, ${ }^{165}$ it is possible, however, that the force of this influence might wane at the clemency stage because of the passage of time, if for no other reason.

\footnotetext{
${ }^{163}$ See supra note 148 and accompanying text.

${ }^{164}$ Of the 776 defendants in the dataset, $598(77.1 \%)$ were not granted clemency; 178 $(22.9 \%)$ received clemency. See BJS, supra note 39.

${ }^{165}$ See supra note 148 and accompanying text.
} 
Regardless of the explanation, defendant race and ethnicity did not appear to inform clemency decisions. Or, more specifically, I did not find that racial or ethnic minorities on death row were any less successful in obtaining clemency than their non-minority counterparts. My finding at the clemency stage comports with prior empirical studies of clemency yet conflicts with widely-held perceptions about the general influence of race in the death penalty context.

Age. Younger defendants were more likely than older defendants to receive clemency. Although it is conceivable that ageism might play some role in clemency decisions, at least two alternative explanations exist.

One explanation flows from the growing unease surrounding the execution of defendants who commit capital crimes as minors. ${ }^{166}$ Clemency grants might be used to blunt potential discomfort associated with such situations. If so, clemency grants to minors or those who committed capital offenses as minors would, by definition, favor relatively younger death row inmates. A systematic removal of younger defendants would skew upward the age profile of those left on death row and who do not receive clemency. It is not that younger death row inmates are intrinsically any more or less attractive candidates for clemency; rather, an effort to avoid executing those who committed capital crimes as minors would generate the observed result. ${ }^{167}$ While this is admittedly one form of age-

${ }^{166}$ See Thompson v. Oklahoma, 487 U.S. 815,838 (1988) (holding that the execution of defendants who were under age sixteen when they committed their offenses is a form of cruel and unusual punishment in violation of the Eighth Amendment by incorporation through the Fourteenth Amendment); see also Patterson v. Texas, $123 \mathrm{~S}$. Ct. 24, 24 (2002) (Stevens, J., dissenting from denial of certiorari) (arguing that the Eighth and Fourteenth Amendments may prohibit the execution of a defendant who was under the age of eighteen at the time he committed his offense); id. (Ginsburg \& Breyer, JJ., dissenting from denial of certiorari) (arguing that the Eighth and Fourteenth Amendments may prohibit the execution of a defendant who was under age eighteen at the time he committed his offense).

${ }^{167}$ The Department of Justice reports that those executed in 2000 spent, on average, just over eleven years on death row. See BJS 2000, supra note 35, at 1 . The typical time lag between a death sentence and execution, therefore, all but precludes the possibility of the execution of a minor. That is, even those defendants who committed capital crimes as minors typically reached the age of majority prior to their execution or clemency grant. 
ism, it pivots on a statutory definition of a minor rather than a pure preference for younger over older defendants.

Researchers also suggest that older defendants have had, by definition, more time during which they could have accumulated a prior criminal record, including felonious conduct. ${ }^{168}$ Defendants with prior criminal records-especially prior felony convictionsare far more attractive candidates for the death penalty to prosecutors, judges, and juries ${ }^{169}$ and therefore far less attractive candidates for clemency. Thus, a defendant's age may simply mask another variable-prior criminal conduct-that, as I discuss below, is expected to influence clemency decisions. I attempt to control for prior felony convictions in Models $\mathrm{A}$ and $\mathrm{C}$. The age variable remains significant in those models, although it has a greater magnitude in Model B where the control variable for prior felonies is absent.

Education Level. Death row inmates with more education were less likely to receive clemency. On the surface, this finding appears odd. After all, to the extent that a defendant's education level is one proxy-however imperfect-for intelligence or, more broadly socioeconomic status, one would expect that the clemency process generally would favor more intelligent and more advantaged defendants. This would be especially true if the quality of legal representation for death row inmates is uneven. Of course, a plausible counter-argument also exists: Juries might act less sympathetically towards more educated or more advantaged defendants if the jurors perceive that these defendants had greater opportunities for noncriminal behavior.

It is more likely, however, that the finding that clemency favors defendants with less education comports with the direction of the Supreme Court's recent Atkins v. Virginia decision, where the Court ruled unconstitutional state execution of mentally retarded criminals. ${ }^{170}$ In Atkins, the Court described at considerable length the recent movement in state legislatures across the country to ex-

16: Blume et al., supra note 148, at 16.

${ }^{169}$ David Baldus et al., Equal Justice and the Death Penalty: A Legal and Empirical Analysis 73 tbl.1, 75 tbl.2 (1990) (noting the significance of a defendant's prior criminal record in death penalty decisions).

${ }^{170}$ Atkins v. Virginia, $122 \mathrm{~S}$. Ct. 2242 (2002) (holding that capital punishment of mentally retarded offenders violates the Eighth and Fourteenth Amendments). 
pressly exempt mentally challenged defendants from the reach of capital punishment. ${ }^{171}$ One explanation of the finding is that clemency decisionmakers share the growing unease with such sentences and are similarly disinclined to execute mentally retarded defendants. ${ }^{172}$ If so, and if one assumes that mental retardation expresses itself in lower educational achievement, then this disinclination could generate a statistical tilt favoring clemency grants for less educated defendants. That is, rather than a pure preference for less educated defendants, this finding might reflect something subtler. Working in a manner parallel to the influence of a defendant's age on clemency decisions, the influence of education level might be a product of clemency decisionmakers' aversion to executing the mentally retarded.

Prior Felonious Conduct. It is widely assumed that prior felonious conduct reduces a defendant's chance for clemency. Prior criminal conduct influences earlier components of the death penalty process. ${ }^{173} \mathrm{~A}$ defendant's criminal history informs jurors' perceptions about the likelihood of future criminal conduct. ${ }^{174}$ General perceptions that a defendant's prior conduct is a predictorhowever imperfect - of future criminal behavior enjoy substantial empirical support. ${ }^{175}$ Congress, through the Sentencing Guidelines, ${ }^{176}$ expressly adjusts a criminal defendant's sentencing range

${ }^{171}$ Id. at 2248-50 (discussing the number of states that passed laws prohibiting the execution of mentally retarded defendants).

${ }^{172}$ For a general discussion see, for example, Aimee D. Borromeo, Mental Retardation and the Death Penalty, 3 Loy. J. Pub. Int. L. 175, 194-95 (2002) (arguing for a reconsideration of the constitutionality of executing the mentally retarded in light of a growing consensus in state legislation).

${ }^{173}$ See supra note 169.

${ }^{174}$ See Eisenberg et al., Forecasting Life and Death, supra note 22, at 290-91 (finding that predictions about future criminal conduct for a defendant influence jurors' votes for the death penalty).

${ }^{175}$ See Jacob Belkin et al., Recidivism as a Feedback Process: An Analytical Model and Empirical Validation, 1 J. Crim. Just. 7 (1973); Alfred Blumstein \& Elizabeth Graddy, Prevalence and Recidivism in Index Arrests: A Feedback Model Approach, 16 Law \& Soc'y Rev. 265 (1981).

${ }^{176}$ In 1984, the Sentencing Reform Act of 1984 became law. Pub. L. No. 98-473, 98 Stat. 1987 (1984) (codified as amended in scattered sections of 18 U.S.C. and 28 U.S.C. $\$ \S 991-998)$. In 1987 Congress adopted the Federal Sentencing Guidelines, which came into effect on November 1, 1987. See U.S. Sentencing Comm'n, Sentencing Guidelines and Policy Statements 1.1, 1.12 (1987); Sisk, Heise \& Morriss, supra note 63 , at 1397. 
upward if he or she has a criminal history. ${ }^{177}$ Consequently, it makes sense that analogous-though distinct-decisions about whether to remove a defendant from death row, which similarly seek to reconcile competing goals of just desert, retribution, and public and prison safety, take into account a petitioner's prior felonies when estimating the likelihood of recidivism. Indeed, in some states clemency decisions must weigh a defendant's prior felonies. ${ }^{178}$

A dummy variable, PRIOR FELONY, signaling those defendants with at least one felony conviction prior to receiving a death sentence, is included in Column (A) ${ }^{179}$ The results in Column (A) reveal that defendants with a prior felony were far less likely to receive clemency. Notably, this finding conflicts with prior research. ${ }^{180}$ This study expands upon prior research by including more data and additional variables, ${ }^{181}$ and thus, the slightly different findings for PRIOR FELONY might stem from differences in the research designs used.

Marital Status. Prior research considers a defendant's marital status and its potential influence on clemency decisions. ${ }^{182}$ Intuition suggests that married defendants are more likely to receive clemency than those who are single, divorced, or widowed. The hypothesis rests on the assumption that a defendant with a loyal spouse seeking to generate support for a favorable clemency decision might gain an advantage. This advantage could flow from the potential external pressure generated by the non-incarcerated spouse. Furthermore, the potential hardship on a spouse (and other family members) generated by an execution could plausibly

${ }^{17}$ U.S. Sentencing Guidelines Manual § 5A (2001) (displaying a sentencing table). For federal drug offenders, two prior convictions for crimes of violence or drugs make an offender eligible for "career offender" status. Those defendants classified as a career offender warrant maximum offense levels. See id. § 4B1.1.

${ }^{178}$ See, e.g., Mont. Code Ann. $\$ 46-23-301$ (2001). In California, the state constitution limits the governor's ability to grant clemency to defendants with prior felonious convictions. Cal. Const. art. V, \$ 8 .

${ }^{177}$ For reasons discussed previously, the model used in Column (B) is identical to the model in Column (A), except for the removal of the PRIOR FELONY variable. See supra Section III.B.4.

See Pridemore, supra note 36 , at 175. It should be noted, however, that Professor Pridemore's models exclude the structural variables included in this study. See id. at 178 n.15. Moreover, the dataset was limited to 1974-1995 data. See id. at 167.

${ }^{181}$ See id. at 170, 172 tbl.3.

${ }^{152}$ See id. at 172 (finding no influence). 
influence clemency considerations. My analysis found that marriage had no effect on clemency, but reasons exist to interpret this finding with caution.

Measuring the effect of marriage is not as simple as it would seem. The data used in this study report defendants' marital statuses at the time the defendant entered death row rather than at the time of execution or removal from death row through clemency. At the time they entered death row, approximately one-third were married, $20 \%$ were divorced, and $40 \%$ had never been married. Because of the extensive appeals processes and a natural time lag, a significant amount of time can pass between a defendant's entry onto death row and the defendant's removal (through execution or a grant of clemency). During this time a defendant's marriage status can change and the data would not capture it. This possibility precludes a full assessment of the hypothesized influence of a defendant's marriage status on clemency decisions. To extract a test of the hypothesis, I assume that those defendants who were married at the time they entered death row remained married until either execution or the grant of clemency. This assumption is dubious given the obvious strains on a marriage imposed by a death sentence (at least a marriage as conventionally understood). Given these strains, it is highly likely that at least some of the defendants who were married when they entered death row subsequently divorced prior to their execution or successful clemency petition.

Despite its restricted utility, prior empirical clemency work includes MARRIED as a variable. ${ }^{183}$ Although some defendants surely divorced after entering death row, others likely remained married. In addition, a defendant's status as married at the time he entered death row might capture subtle characteristics that could, conceivably, influence clemency decisions. Of course, these characteristics do not bear squarely on the standard hypothesis of interest, namely, whether the existence of a death row inmate's spouse could influence clemency decisions. ${ }^{184}$ In any event, results in Table

\footnotetext{
${ }^{183}$ Oddly, Professor Pridemore's work does not address the timing problem flowing from the MARRIED variable. See id. at 172.

${ }^{184}$ Unless, of course, one is willing to assume away the possibility of divorce after a defendant enters death row.
} 
3 show that a defendant's marriage status played no role in clemency decisions and comport with prior clemency research. ${ }^{185}$

\section{B. Political Variables}

By definition, a state's use of the death penalty is a political act. ${ }^{186}$ Decisions about whether citizens are executed or spared death by the state involve the exercise of one of the highest forms of political power. It is no surprise to find some level of politicization surrounding virtually all aspects of the death penalty. Indeed, according to the functions clemency fulfills, political factors are supposed to play some role. The interesting question is not whether political factors influence clemency decisions, but which ones do so. Examining the influence of these political factors is important as many death penalty critics point to them as contributing to the inconsistent application of the death penalty. ${ }^{187}$ Political factors examined in this study include presidential and gubernatorial election cycles, whether a governor granted clemency during an administration's "eleventh hour," whether state court judges are elected, and a governor's background characteristics.

Presidential Election Year. A presidential candidate's position on the death penalty receives considerable public attention during the campaign season. The salience of the death penalty issue as campaign fodder has increased over the years. Some commentators point to Michael Dukakis's response to a death penalty question during a nationally televised debate as contributing to his defeat. ${ }^{188}$ During 1992, while campaigning for the presidency, then-Governor of Arkansas, Bill Clinton, famously flew from New Hampshire to Arkansas during the height of the campaign season to deny a clem-

\footnotetext{
${ }^{18 s}$ See, e.g., Pridemore, supra note 36 , at 172 tbl.3.

${ }^{1 \times s}$ See The Rights and Wrongs, Economist, May 12, 2001, at 11 (noting that the death penalty is the "strongest" message a society can make).

${ }^{157}$ See, e.g., Kenneth Bresler, Seeking Justice, Seeking Election, and Seeking the Death Penalty: The Ethics of Prosecutorial Candidates' Campaigning on Capital Convictions, 7 Geo. J. Legal Ethics 941 (1994) (noting the pressures generated by prosecutors' electioneering); Ronald J. Tabak,.Politics and the Death Penalty: Can Rational Discourse and Due Process Survive the Perceived Political Pressure?: Commentary, 21 Fordham Urb. L.J. 280, 280-81 (1994) (noting the perceived political pressures associated with death penalty decisions).

${ }^{1 \$ S}$ See supra note 24.
} 
ency petition and sign a death warrant for the execution of a braindamaged defendant. ${ }^{189}$

PRESIDENT ELEC YEAR, identifying clemency decisions announced during the calendar year, was designed to assess whether presidential electoral politics influenced clemency decisions. Strong reasons exist to doubt the potential influence of presidential elections. After all, neither presidents ${ }^{190}$ nor presidential candidates ${ }^{191}$ have much to do directly with whether a defendant in any particular state is put to death or granted clemency. Indirect links between presidential elections and state-level clemency decisions suggest a possible source of influence, however. For example, presidential political campaigns invariably increase public debate on the death penalty as well as a host of other standard political issues. ${ }^{192}$ Additionally, political scientists have long noted the influence of presidential elections upon gubernatorial elections. ${ }^{193}$ Finally, recent presidential electoral experience supplies anecdotal evidence of a possible influence. Specifically, how then-candidates, Clinton and Bush, managed their death penalty-related duties as governors during their respective presidential campaigns attracted considerable attention. ${ }^{194}$

${ }^{189}$ See Jordan, supra note 10 , at 19 (expressing outrage at Clinton's execution of Ricky Rector); see also Thomas B. Edsall, 3 Democrats Now Willing to Support Death Penalty: Candidates Abandon Traditional Liberal Tenets, Wash. Post, Jan. 23, 1992, at A14 (reporting the growing acceptance of the death penalty among Democratic candidates).

${ }^{190}$ Presidents do, of course, possess Article II pardon authority, which enables them to pardon defendants found guilty of "offenses against the United States, except in cases of impeachment." See U.S. Const. art. II, § 2. However, the small number $(\mathrm{N}=21)$ of defendants convicted of federal crimes and sentenced to death between 1973 and 1999 has been excluded from this study. See supra Section III.B.1.

${ }^{191}$ I recognize, however, that a more direct link exists when a presidential candidate happens to be a sitting governor, as was the case with Bill Clinton in 1992 and, more recently, George Bush in 2000.

${ }^{192}$ See supra Section I.A.

${ }^{193}$ See, e.g., Samuel C. Patterson \& Gregory A. Calderia, Getting Out the Vote: Participation in Gubernatorial Elections, 77 Am. Pol. Sci. Rev. 675, 677-78 (1983) (noting that voter turnout for gubernatorial elections is higher in presidential election years). See generally Malcolm E. Jewell \& David M. Olson, American state political parties and elections (rev. ed. 1982) (comparing political party and elections' systems across fifty states).

${ }^{194}$ For example, it is hard to ascribe to anything but presidential campaign pressures then presidential candidate Bill Clinton's infamous trip to Arkansas to preside over the execution of a brain-damaged defendant. See supra note 189 and accompanying 
Despite the existence of indirect links and contrary anecdotal evidence, the results in Table 3 reveal no systematic link between clemency decisions and presidential election years. While the data support the hypothesis that presidential campaigns were confined to electoral rhetoric and did not bleed into clemency decisions, an alternative interpretation of this finding is that presidential election cycles offset one another. That is, depending on public opinion at any moment in time, one presidential election cycle may have prompted an increase in clemency grants, while another presidential election cycle may have prompted a decrease. If so, presidential election years would be influential, just not discernable to empirical detection.

Governor Election Year. Although the link between presidential elections and clemency decisions is arguably attenuated, the link between gubernatorial elections (and re-elections) and clemency decisions is far more direct and robust. Researchers note that state elections influence other state-level activities, ranging from taxing and spending issues ${ }^{195}$ to police hiring. ${ }^{196}$ Moreover, prior research has asserted that defendants are less likely to receive clemency during an election year. ${ }^{197}$ Commentators have noted the possibility that governors seeking to "ingratiate themselves with a fearful and vengeful electorate" might alter their clemency decisions with an eye toward elections. ${ }^{198}$ Thus, state elections' potential influence on

text. Then-Governor Bush no doubt faced similar pressures as they related to the execution of a women defendant, Karla Faye Tucker, in 1998. See Jeffrey L. Kirchmeier, Another Place Beyond Here: The Death Penalty Moratorium Movement in the United States, 73 U. Colo. L. Rev. 1, 59-60 (2002); Andrea Shaprio, Unequal Before the Law: Men, Women and the Death Penalty, 8 Am. U. J. Gender Soc. Pol'y \& L. 427, 431 (2000) (describing the execution of Tucker); John Harwood, Bush May Be Hurt by Handling of Death-Penalty Issue, Wall St. J., March 21, 2000, at A28 (arguing that a decline in public backing for the death penalty could complicate George W. Bush's presidential campaign).

${ }^{19 s}$ See, e.g., James M. Poterba, State Responses to Fiscal Crises: The Effects of Budgetary Institutions and Politics, 102 J. Pol. Econ. 799 (1994) (addressing state tax and spending levels during the late 1980s).

${ }^{1 s s}$ See, e.g., Steven D. Levitt, Using Electoral Cycles in Police Hiring to Estimate the Effect of Police on Crime, 87 Am. Econ. Rev. 270 (1997) (discussing police hiring).

${ }^{157}$ See Pridemore, supra note 36, at 172, 176.

${ }^{15:}$ Coleen E. Klasmeier, Towards a New Understanding of Capital Clemency and Procedural Due Process, 75 B.U. L. Rev. 1507, 1513-14 (1995). For a discussion of how the 1990 gubernatorial contests in Texas, California, and Florida offer glimpses 
clemency decisions, especially in states that vest clemency authority with their governors, is commonly assumed. To assess this potential influence, GOVERNOR ELEC YEAR marks death row removals that took place between January and October during a gubernatorial election year.

Despite gubernatorial elections' more direct link to clemency decisions, GOVERNOR ELEC YEAR did not achieve statistical significance. Although these results suggest that gubernatorial election politics do not systematically influence decisions, it is important to note what these data do not reveal. Specifically, gubernatorial electioneering may well influence clemency, but perhaps not the outcome of specific death row removals. For example, it remains entirely possible that a governor can delay acting on a clemency petition or, indeed, influence execution dates themselves, with an eye toward a state election calendar. This more subtle potential influence is beyond the scope of these data, however.

Exit Clemency. Anecdotal evidence, both at the state ${ }^{199}$ and fed$\mathrm{eral}^{200}$ levels, suggests that clemency decisions by an executive officer at the close of an administration might vary from decisions made at other times during an administration. The logic behind this possibility is straightforward, and incentive structures play an important role. To the extent that clemency grants to death row inmates are politically unpopular and risk inflicting political damage to a granting governor, a governor departing office after an adverse election result, a term limitation, or a decision not to run again presumably is less sensitive to those costs. ${ }^{201}$ The political incentives that inform the governor's clemency decisions-indeed, the incen-

into the new politics of death, see, for example, Richard Lacayo, The Politics of Life and Death, Time, Apr. 2, 1990, at 18; see also Lucy Howard \& Ned Zeman, 1-800Death, Newsweek, July 8, 1991, at 6 (reporting that a Nebraska senator established toll-free number so death penalty boosters could register support for the execution of Harold Otey).

${ }^{199}$ In 1986, New Mexico Governor Toney Anaya granted clemency to five death row inmates. Similarly, Ohio Governor Richard Celeste granted clemency to eight death row inmates (including four female inmates) prior to leaving office in 1991. See Pridemore, supra note 36 , at 168 n.7.

${ }^{200}$ For a brief summary of "eleventh-hour" pardon authority exercised by former Presidents Clinton and Bush, see Sisk, supra note 10, at 14-18.

${ }^{201}$ See Hugo Adam Bedau, The Decline of Executive Clemency in Capital Cases, 18 N.Y.U. Rev. L. \& Soc. Change 255, 270 (1990-91) (observing that governors often commute death sentences only when they no longer have future political ambitions). 
tives that distinguish the pure executive and administrative models-recede as the end of governor's term arrives. ${ }^{202}$ In fact, the temptations offered by the eleventh-hour pardon are significant enough-and the prospect for abuse realistic enough-that some legal scholars have called for a reduction of Article II pardon authority during presidential administration transition periods, or during the period of "greatest jeopardy."

To assess the possibility of an eleventh-hour influence on clemency decisions, EXIT CLEMENCY identifies clemency grants during the months of December and January, following a governor's election defeat or retirement from office. ${ }^{204}$ Despite notable anecdotal evidence as well as a governor's evolving incentives, the clemency decisions by soon-to-be departing governors and decisions made by governors at other times during their terms did not systematically vary. That is, the hypothesized eleventh-hour influence on clemency decisions was not detected.

Elected State Court Judges. Although neither presidential nor gubernatorial elections influenced clemency decisions, state judicial elections might have had just such an effect. States that elect

${ }^{202}$ To be sure, some exiting governors may have their eyes fixed on other elected offices in the future. If so, their political incentives, while diluted somewhat, remain largely intact.

${ }^{2}$ See Sisk, supra note 10, at 26-27 (supporting a proposed constitutional amendment that would restrict an out-going president's Article II pardon authority).

${ }^{2 * 4}$ This variable would also include governors that decided to not run for re-election as well as those who may have been precluded from additional terms.

In at least two notable instances, lame-duck governors granted multiple clemencies in the two months prior to the close of the term of office. Former New Mexico Governor Anaya in 1986 and former Ohio Governor Celeste in 1991 granted multiple "exit clemencies." Indeed, Anaya's gesture was so stark that at least one researcher decided to remove her clemencies from his study. See Pridemore, supra note 36 , at 168 n.7. A more recent example (though one outside this study's time frame) is Illinois Governor Jim Ryan's commutation of all of Illinois's death row inmates two days before his term as Governor expired. Governor Ryan's exercise of massive "exit clemency" affected 156 death row inmates, as well as eleven others sentenced to death but not yet on death row because of re-sentencing or trials in other cases. Given the magnitude of Governor Ryan's action on January 11, 2003, it is clear that its inclusion in future BJS datasets will influence future results. Aside from dramatically increasing the probability that EXIT CLEMENCY will achieve statistical significance in the future, the full impact of Governor Ryan's blanket commutation on future clemency studies will not emerge until the data become available for analyses. See Jeff Flock, Blanket Commutation Empties Death Row, CNN.com, at http://www.cnn.com/2003/LAW/01/11/illinois.death.row/index.html (Jan. 13, 2003). 
rather than appoint their highest judicial officers might generate election campaigning that bears squarely on the death penalty. ${ }^{205} \mathrm{~A}$ recent Supreme Court decision, Republican Party of Minnesota $v$. White, ${ }^{206}$ upholding a judge's First Amendment right to discuss matters in an election that the judicial canons preclude, will likely broaden the range of issues discussed by judicial candidates. Given the public's general support for the death penalty, ${ }^{207}$ state judges, especially those subject to election for their selection and retention, might be more reluctant than appointed judges to question capital convictions. ${ }^{208}$ At least one study finds that elected state trial judges are more likely to override jury conclusions and impose death sentences. ${ }^{209}$ Moreover, these factors, individually and cumulatively, might also inform a governor's or, to a lesser extent, an administrative board's clemency decisions.

By judicial elections, I refer to the partisan and non-partisan election of a state's highest judges, and I rely on traditional classifications of states that elect and appoint their highest judges. ${ }^{210}$ Through ELEC. ST. JUDGES, I explore possible differences in clemency decisions between states that elect high court judges and

${ }^{205}$ See Randall Coyne \& Lyn Entzeroth, Report Regarding Implementation of the American Bar Association's Recommendations and Resolutions Concerning the Death Penalty and Calling for a Moratorium on Executions, 4 Geo. J. on Fighting Poverty 3,13 (1996) ("The death penalty and politics . . are inseparable," particularly because "the vast majority of judges who preside over capital cases must answer to the electorate" and because "judges are far less likely to ... take ... tough action if they must run for reelection or retention every few years"') (quoting Am. Bar Ass'n. Report of the Commission on Professionalism, 112 F.R.D. 243, 293 (1986)).

${ }^{206} 536$ U.S. 765 (2002) (holding that a judicial canon that prevented a judicial candidate from discussing views on disputed legal and political issues violates the First Amendment).

${ }^{207}$ See supra Section I.A.

${ }^{208}$ See Harris v. Alabama, 513 U.S. 504, 519-20 (1995) (Stevens, J., dissenting) (noting the dangerous pressures placed upon elected state judges who must profess their fealty to the death penalty); Liebman et al., supra note 21 , at $100,101 \&$ fig. 28,102 \& fig.29, 103 (suggesting a relationship between elected trial judges and their decisions in death penalty cases); Blume \& Eisenberg, supra note 38, at 475 ("Capital punishment-related campaigns may lead those judges subject to partisan elections to be more reluctant than other judges to question capital convictions."); Bright \& Keenan, supra note 116, at 776 (noting that rulings in capital cases can "significantly affect whether a judge remains in office or moves to a higher court").

${ }^{209}$ See Burnside, supra note 78, at 1039.

${ }^{210} \mathrm{See}$ F. Andrew Hanssen, The Effect of Judicial Institutions on Uncertainty and the Rate of Litigation: The Election Versus Appointment of State Judges, 28 J. Legal Stud. 205, 214 fig.1 (1999). 
states that appoint. As Professors Blume and Eisenberg note, however, alternative classifications of state judicial selection methods exist and deserve study. ${ }^{211}$ For example, one could compare those judges selected in partisan elections with all other judges and also compare states with merit selection with those states lacking such mechanisms. Researchers who have focused on any of the traditional axes and considered derivations typically do not find material differences. ${ }^{212}$

Results from my study did not uncover a difference in clemency decisions based upon a state's method for selecting its highest judges. Whether state judicial election issues might influence judicial behavior in other death penalty matters ${ }^{213}$ is beyond the scope of this study and these data. Any spillover effects flowing from state judicial elections did not influence clemency decisions, however.

Governor Background Variables. Consistent with the other political factors, none of the governors' background variables achieved statistical significance. Interestingly, despite widespread popular perceptions that women, Democrats, and Catholics view the death penalty with less favor, ${ }^{214}$ the results indicate that these characteristics had no effect on clemency decisions. The same is true for older governors and governors with legal training. Although the coefficients for variables indicating female, Democratic, and Catholic governors are negative, suggesting that governors possessing these characteristics were less likely to grant clemency, the coefficients for older governors as well as those with legal training were positive, suggesting they were more likely to grant clemency, these differences did not achieve statistical significance. It is surprising that no differences emerge between Democratic and

\footnotetext{
${ }^{211}$ See Blume \& Eisenberg, supra note 38, at 476 (explaining that alternative judicial selection methods do not affect results).

${ }^{212}$ Id.

${ }^{213}$ See generally Burnside, supra note 78 (arguing that elected judges should not be permitted to use the jury override because they have a personal interest in the outcome of the case).

${ }^{214}$ Whether these popular perceptions are accurate is unclear. For example, Pope John Paul II's strong stance against the death penalty is well known even outside Catholic circles and fuels a perception that Catholics are more likely to oppose the death penalty. See Pontiff Urges End to Death Penalty, L.A. Times, Dec. 26, 1998, at A10. It is not clear how many Catholics share the Catholic hierarchy's position on the death penalty.
} 
Republican governors, given the amount and type of rhetoric that typically surround death penalty issues in the political campaign contexts. Although gender plays a strong role in determining who receives clemency, a governor's gender does not play a strong role in the decision. It appears, then, that clemency is a tool for all governors that can be deployed in an effort to demonstrate their willingness to "get tough" on crime. ${ }^{215}$

Unexpectedly, none of the political variables examined in this study achieved statistical significance. ${ }^{216}$ Although previous cautions about the interpretability of negative findings endure, ${ }^{217}$ these findings run counter to widely held beliefs about the relationship between politics and clemency decisions. ${ }^{218}$ The findings remain remarkably robust, spanning time ${ }^{219}$ as well as the type of decisionmaking model. ${ }^{220}$ The absence of significant political variables is especially surprising given the death penalty's deep entrenchment in the political processes.

Of course, one cannot conclusively state that political factors did not influence clemency decisions, and no such conclusion should be drawn from these findings. A more precise-and narrowerinterpretation of these findings is simply that the political variables considered in this study did not emerge as significant. Other political variables, perhaps more subtle than those included in this study,

${ }^{215}$ See Pridemore, supra note 36, at 176 (discussing the "get tough" hypothesis as it applies to a gubernatorial election year effect).

${ }^{216}$ The fact that the absence of significant political variables persists in the supplemental run, which considers only clemency decisions in states that vest their governors with sole clemency authority is even more surprising. See infra Section IV.E.

${ }^{217}$ See supra note 157 .

${ }^{218}$ See, e.g., Kobil, supra note 7, at 607-11 (describing how political pressures inform clemency decisions); Henry Pietrkowski, The Diffusion of Due Process in Capital Cases of Actual Innocence After Herrera, 70 Chi.-Kent L. Rev. 1391, 1428-29 (1995) (arguing that political factors influence clemency decisions); Jill Hanson Reinmuth, Note, When Actual Innocence is Irrelevant: Federal Habeas Relief for State Prisoners after Herrera v. Collins, 69 Wash. L. Rev. 279, 298 (1994) (arguing that "political mood swings may unduly influence clemency decisions").

${ }^{219}$ The results in Column (C)-post-1984 - do not substantially differ from those reported in Columns (A) or (B).

${ }^{220}$ The absence of statistically significant political variables persists even when I examine only those states that vest their governors with sole clemency decisionmaking authority. See infra Section IV.E and Table 4. 
could prove important. ${ }^{221}$ Moreover, political factors surrounding individual clemency decisions might be unique and resist statistical aggregation, at least in any discernable pattern. Put simply, political factors may exist in the clemency context in ways that resist empirical detection. For example, salient political factors might inform clemency decisions but be highly idiosyncratic and casespecific. Limitations notwithstanding, the fact that one longassumed contributor to inconsistent and arbitrary clemency decisions-political factors-did not emerge as significant in this study remains important, especially insofar as the findings conflict with conventional wisdom and isolated incidents.

\section{Structural Variables}

Clemency Decisionmaking Models. The results illustrate that the structure of clemency authority influenced clemency decisions. ${ }^{223}$ I considered three basic models of clemency decisionmaking authority: executive, administrative, and a blend of the two. ${ }^{24}$ The results comport with the theory that favorable clemency decisions are

${ }^{21}$ See, e.g., Kobil, supra note 7, at 608 (describing how former California Governor Edmund "Pat" Brown denied clemency for Richard Lindsey after learning that a legislator who favored Lindsey's execution would withhold support from an important farm labor bill if Governor Brown granted clemency).

${ }^{222}$ See supra notes 193-94 and accompanying text (describing conventional wisdom that links political pressures to clemency decisions).

${ }^{22}$ To be sure, clemency decisions are assumed to be taken quite seriously by decisionmakers in all models. See, e.g., Brown \& Adler, supra note 113, at 163 (noting former California Governor Edmund "Pat" Brown's description of executive clemency as an "awesome, ultimate power over the lives of others"); Daniel T. Kobil, Due Process in Death Penalty Commutations: Life, Liberty and the Pursuit of Clemency, 27 U. Rich. L. Rev. 201, 223 (1993) ("Without doubt, an empirical study of clemency practices in jurisdictions which employ the death penalty would demonstrate that virtually all capital clemency requests are closely scrutinized by the decisionmaker."); Silverman, supra note 71, at 391-93 (describing accounts of two governors' methods for reviewing clemency petitions in states that vest decisionmaking authority in the governor).

${ }^{224}$ With each state's clemency decisionmaking authority falling into one of three models, and the presence of each model captured by a distinct dummy variable, I selected the blended model as the reference group and, as a result, omitted it from the model. The blended group was a particularly attractive and logical reference group because I was most interested in the possible influence of the two models that generate the clearest contrast: the executive and administrative models. The selection of the blended group as the reference did not distort the results. See supra note 106. For a discussion of reference group selection, see Hardy, supra note 90, at 9-12. 
more likely from administrative boards. Specifically, sole clemency authority vested with an administrative board increased the probability of a favorable clemency petition. This statically significant finding persisted across all three regression models.

The most likely explanation for this result comports with what theory predicts: Administrative boards are more insulated from direct political and popular pressures than popularly elected governors and therefore more likely to reach decisions that conflict with public opinion. Although public opinion surrounding clemency for any particular defendant in any given state can vary, sometimes considerably, general public support in the United States for the death penalty has remained at about $65 \%$ during the past decade. ${ }^{225}$ With more than one-half of the public in approval of the death penalty, and in light of a defendant's death sentence having been meted out by a jury, it is fair to assume that a decision to grant a defendant's clemency petition would generally run against public opinion. ${ }^{226}$

This explanation is not without some irony. The emergence of the administrative models of clemency decisionmaking authority during the first half of the twentieth century owes a debt to perceived (or actual) abuses of clemency authority by governors. ${ }^{27}$ Specifically, the perception that political factors were prompting governors to grant clemency too often stimulated a movement in some states to shift clemency decisionmaking authority from governors to more politically insulated administrative boards. ${ }^{228}$ That

\footnotetext{
${ }^{225}$ See supra note 23 and accompanying text.

${ }^{206}$ In unusual situations, however, such as where unambiguous DNA evidence emerges and casts severe doubt as to a defendant's actual guilt, public opinion can easily tilt in favor of granting clemency. See Kirchmeier, supra note 194, at 39-43 (describing how DNA evidence that emerges and exonerates those convicted of murder raises public awareness of the problems with the justice system).

${ }^{227}$ See Christen Jensen, The Pardoning Power in the American States 11 (1922); Abramowitz \& Paget, supra note 117, at 141.

${ }^{228}$ See Jensen, supra note 227 , at 11 . Fears that governors would sell pardons influenced some states. See Abramowitz \& Paget, supra note 117, at 141. A desire to prevent governors from liberally construing pardon authority was also present. See id.; see also Korengold et al., supra note 2 , at $355 \&$ n. 72 (finding that states often establish administrative boards to reduce the governor's power in granting clemency).
} 
administrative boards were more likely than governors to grant clemency since 1973 effectively turned earlier fears on their head. ${ }^{229}$

If enhanced insulation from popular political sentiment is one major reason states vest clemency authority in an administrative board rather than a governor, ${ }^{230}$ these results suggest that administrative boards accomplish what they were designed to do. When a governor makes an unpopular clemency decision, dissatisfied voters can express their displeasure directly through the ballot box. Yet, when an unelected administrative board-the members of which are frequently unknown to the public-makes a similarly unpopular decision dissatisfied voters lack a similarly clear target for their displeasure. Although it is possible that voters might hold governors vicariously liable for decisions made by administrative boards, ${ }^{231}$ such a result appears unlikely and, in any event, would be largely ineffective. ${ }^{232}$

Governors can certainly influence purely administrative boards, principally through appointments to the board. ${ }^{233}$ Although the in-

${ }^{229}$ Even this potentially ironic finding, however, might comport with classic views of the behavior of bureaucracies that, in part, feel compelled to "do something" or implement their mandate. In this specific context, the mandate involves assessing clemency petitions. A need to do something might tilt administrative clemency boards toward granting rather than denying clemency. For a broader theoretical framework and discussion, see Max Weber, The Theory of Social and Economic Organization (Talcott Parsons ed., A.M. Henderson \& Talcott Parsons trans., Oxford Univ. Press 1st ed. 1947).

${ }^{230}$ For a description of the various administrative models, see supra notes $71-73$ and accompanying text.

${ }^{231}$ For a discussion about how Texans supporting the clemency petition for Gary Graham mistakenly assumed that Texas Governor Ann Richards could grant clemency absent a clemency recommendation from Texas Board of Pardons and Paroles, see Silverman, supra note 71 , at 390 .

${ }^{232}$ What is clear is that elected officials who make unpopular clemency decisions face increased exposure to electoral wrath. This provides indirect evidence that voters are capable of directing their displeasure with clemency (or death penalty) decisions to the decisionmakers. See, e.g., Blume \& Eisenberg, supra note 38, at 470-75 (describing campaigns to oust judges based on death penalty decisions); Scott G. Parker \& David P. Hubbard, Comment, The Evidence for Death, 78 Cal. L. Rev. 973, 101314 (1990) (noting that California voters' concerns about the death penalty played a key role in the 1986 retention elections but a comparably smaller role in the state's gubernatorial election).

${ }^{233}$ See Clifford Dorne \& Kenneth Gewerth, Mercy in a Climate of Retributive Justice: Interpretations from a National Survey of Executive Clemency Procedures, 25 New Eng. J. on Crim. \& Civ. Confinement 413, 444 (1999) (noting the possibility that 
fluence is not direct, loyal administrators can accomplish a governor's bidding. A governor seeking to influence future clemency decisions through board appointments may be frustrated, however, by appointees who do not remain loyal to the appointing governor's wishes. ${ }^{234}$ This analysis supports the conclusion that altering the location of decisionmaking authority can make a difference even when governors continue to exert indirect influence.

At least one structural aspect distinguishing executive and administrative models might reduce the possibility that administrative boards would act against public opinion. In a pure executive model, a governor need only persuade herself of the merits of a clemency petition. In contrast, administrative models typically involve a group where consensus is required. As the number of decisionmakers involved increases, so too does the potential complexity of the decision and decisionmaking process. Moreover, in administrative models individual responsibility for each board member is diluted, at least in comparison to the sole responsibility assigned to a governor in an executive model. Board members might not feel as personally vested in a group decision on a clemency petition as governors might feel when they exercise plenary authority. ${ }^{235}$ With less of a personal stake, it is plausible that board members have less incentive to invest themselves in clemency petitions and less reason to disrupt a death sentence. ${ }^{236}$ As plausible as this theory might be, however, it does not find support in the results.

governors seek political "window dressing" through their appointments to clemency boards).

${ }^{234}$ One obvious analogy is to the inherent uncertainty experienced by presidents who seek to influence legal decisions through appointments to the federal bench. Many presidents have been quite surprised by decisions of some of their own appointees. See Should Ideology Matter? Judicial Nominations: Hearing Before the Subcomm. on Admin. Oversight and the Courts of the Senate Comm. on the Judiciary, 107th Cong. (2001) (statement of Sen. Orrin G. Hatch, Ranking Member, Senate Comm. on the Judiciary), reprinted in 50 Drake L. Rev. 429, 501 (2002) (noting the unpredictability of federal judges once confirmed to the federal bench and commenting that "history is replete with examples of judges who surprised even the very Presidents who appointed them").

${ }^{235}$ See, e.g., Silverman, supra note 71 , at 393-94 (exploring the dilution-ofresponsibility problem with pardoning boards).

${ }^{236}$ The status quo would be to allow an execution to go forward. See id. at 394 (describing as "unlikely" the probability that a state might draft a clemency statute that would grant clemency absent an affirmative board recommendation to the contrary). 
What these results demonstrate is that the manner in which states structure clemency decisionmaking authority matters. Consequently, a defendant "lucky" enough to be sentenced to death in a state that vests clemency authority in an administrative board is comparatively better off than his counterpart sentenced to death in a state where the governor makes clemency decisions. Of course, the prospects for a successful clemency petition-even those from death row inmates residing in states with administrative clemency boards-remain statistically $\operatorname{dim}^{237}$ Even as the overall prospects for clemency diminish, however, how states structure clemency decisionmaking authority influences clemency decisions.

Regionality. The South has long been perceived to be a problem in death penalty reform circles. ${ }^{238}$ It is clear that a regional component factors into whether a state has a death penalty. All states in the former Confederacy have a death penalty while several states that were not part of the Confederacy do not. ${ }^{239}$ Southern states' generally higher murder rates interact with death penalty statutes and generate a robust execution rate. ${ }^{240}$ Commentators note, "southern society and southern justice are thought to be more punitive and more violent than elsewhere in the country."241 Whether the data bear out the perception surrounding the death penalty's application in the South remains in some dispute. ${ }^{242}$

The results reveal that a "southern effect," long thought to influence death sentencing, also influenced clemency decisions. Specifically, defendants in the South were less likely to receive a favor-

${ }^{237}$ Of the 776 defendants in the dataset, $178(22.9 \%)$ received clemency.

${ }^{23 \times}$ See Am. Civil Liberties Union, Geography Determines Death Sentences, at http://www.aclu.org/news/newsprint.cfm? $\mathrm{WD}=98008 \& \mathrm{c}=62$ (Mar. 8, 2002) (on file with the Virginia Law Review Association) (noting that of the more than 700 executions during the last twenty-five years, Texas and Virginia have "accounted for almost onehalf"). But see David C. Baldus et al., Equal Justice and the Death Penalty: A Legal and Empirical Analysis 235 (1990) (noting that the South did not have the regional variation in death penalty rates that the researchers expected because "the larger numbers of death sentences imposed by Southern states were associated with larger numbers of murder prosecutions"); Blume et al., supra note 148, at 14 (arguing that the specificity of a state's death penalty law is a better correlate of death penalty proclivity than regionality).

${ }^{239}$ Blume et al., supra note 148, at 14.

${ }^{245} \mathrm{Id}$.

${ }^{241}$ Pridemore, supra note 36 , at 167.

${ }^{242}$ Blume et al., supra note 148 , at 14 (finding that although the South may have an especially high murder rate, it does not have a particularly high death penalty rate). 
able clemency decision. This regional effect holds true independent of how a state structures clemency authority. Notably, the southern effect's significance diminished slightly after 1984 (Column (C)). This finding is particularly important given that the South is responsible for a high proportion of all death sentences.

Timing. Defendants were less likely to receive clemency after 1984. Three factors account for this. First, a substantial number of death row inmates had not yet fully exhausted their appeals by 1984, and clemency petitions are typically not filed until all legal avenues have been pursued. This natural lag in the filing of clemency petitions, combined with a general overall decline in clemency grants over time, increased the likelihood of a clemency denial after 1984. Second, by 1984, the constitutional clarity surrounding state death penalty statutes largely gelled. The Supreme Court, in a series of decisions launched by its 1972 Furman v. Georgia ${ }^{243}$ decision, addressed lingering ambiguity surrounding the constitutionality of the death penalty. ${ }^{244}$ As constitutional questions surrounding the states' application of the death penalty were resolved, states began to impose the death penalty and execute inmates with greater frequency.

A final factor is that, at the same time the constitutionality of state death penalty statutes was being clarified by the courts, governors became increasingly reluctant to grant clemency. ${ }^{245}$ The raw number of clemency grants between 1973-1984 and 1985-1999 decreased from 105 to $73 .{ }^{246}$ Between these same two periods the number of executions jumped from 32 to $566 .{ }^{247}$ Relative to the number of executions, the number of successful clemency petitions diminished substantially after $1984 .{ }^{248}$ Both factors, independently and collectively, explain the results for POST-1984.

${ }^{243} 408$ U.S. 238 (1972).

${ }^{244}$ See Gregg v. Georgia, 428 U.S. 153 (1976) (approving numerous state death penalty statutes as they addressed such problems as arbitrariness and discrimination, identified as concerns by the Court in Furman); Zant v. Stephens, 462 U.S. 862 (1983) (providing an example of the Court's later dismantling of most of the procedural restrictions on state death penalty practices imposed by Gregg); Barclay v. Florida, 463 U.S. 939 (1983) (same); Blume \& Eisenberg, supra note 38, at 480 n.53.

${ }^{245}$ See supra notes $46-48$ and accompanying text.

${ }^{246}$ See supra Figure 3.

${ }^{247}$ See supra Figure 2.

${ }^{244}$ See supra Section I.B. Compare supra Figure 2 with Figure 3. 


\section{Post-1984}

The Furman v. Georgia decision influenced capital punishment in the United States in important ways. ${ }^{249}$ It is difficult to overestimate the influence of changes in the number of executions and clemency grants before and after 1984. Consequently, it is important to assess a possibly independent effect on clemency. The significance of the POST-1984 variable in both variants of the full model (Columns (A) and (B)) provides strong inferential evidence that clemency decisions vary before and after 1984. To help isolate the independent influence of the Furman decision and the related timing variable on clemency decisions, in a separate model, I limited the sample to death sentence removals that took place after $1984 .^{250}$ Column (C) in Table 3 presents results from the post-1984 model.

A comparison of Columns (A) and (B) with (C) suggests that the overall influence of the Furman decision, while important, did not disrupt the findings. Where changes emerged, Furman's influence tended to increase the magnitude of the existing findings rather than introduce any new findings. Notably, all of the political variables remained unchanged: That is, they remained nonsignificant. After 1984, the importance of two variables increased: FEMALE and PURE ADMINISTRATIVE. Women defendants, already more likely to receive clemency, were even more likely to receive a gender preference after 1984. Likewise, the influence of structure increased: States with administrative boards with sole clemency decisionmaking authority correlated more strongly with successful clemency petitions.

The degree of statistical significance in two variables, AGE and SOUTH, in the post-Furman analysis lessened. Specifically, while older defendants remain less likely to receive clemency than their younger counterparts, the statistical salience of a defendant's increased age diminished slightly after 1984 . The influence of region-

\footnotetext{
${ }^{249}$ See, e.g., Blume \& Eisenberg, supra note 38, at 479-80; Pridemore, supra note 36, at 175 (noting that "[g]overnors seemed jittery in the years following Furman").

${ }^{25 / 9} \mathrm{I}$ examine pre- and post-1984 cases to facilitate replication of important prior work using the BJS dataset and because by 1985 the Court had dismantled most of the restrictions placed upon capital sentencing in Gregg and other death penalty cases. See Blume \& Eisenberg, supra note 38, at 479 \& n.53, 480; Gross \& Mauro, supra note 38 , at 13 n.30.
} 
ality (SOUTH) similarly diminished. Although southern states remained less inclined to grant clemency, the southern influence waned after 1984.

Perhaps the only surprising, dramatic, and perplexing change is that the statistical significance of one variable-PRIOR FELONYdisappeared altogether after 1984. Prior to 1985 defendants convicted of prior felonies were significantly less likely to receive clemency. This finding, of course, is what one would expect. After 1984, however, prior felonious conduct no longer exerted independent influence on clemency decisions.

That PRIOR FELONY drops out of significance after 1984 both enhances and degrades this finding's stability. By falling out of statistical significance, the post-1984 PRIOR FELONY now comports with prior research. ${ }^{251}$ The variable's stability is undermined, however, because little exists to explain why the results should change before and after 1984.

At the risk of seeking to explain the inexplicable, one potential explanation relates back to a prior point about the dramatic increase in the number of executions and the concurrent decrease in the number of clemency grants. As discussed previously, clemency grants have never been common. Moreover, Table 3 illustrates that the already small number of grants generally trended downward over time. After 1984, the absolute and relative number of clemency grants diminished considerably. Such a diminishment in the dependant variable (COMMUTE) reduces the space in which the variation necessary for empirical analysis arises. This reduction, in turn, could make coefficients for some variables less stable.

\section{E. Political Factors Influencing Governors}

Results from the general model-and all its variants-suggest that many standard political factors assumed to influence clemency decisions might be overstated. As previously discussed, this finding is inconsistent with conventional wisdom. ${ }^{252}$ Again, these results do not preclude the influence of any political factors. Rather, the more narrow point is that none of the political factors studied emerged as significant.

\footnotetext{
${ }^{251}$ See Pridemore, supra note 36, at 175.

${ }^{252}$ See supra Section IV.B.
} 
The absence of statistically significant results is notable and surprising. ${ }^{253}$ One explanation might be that combining states with pure executive models and states with pure administrative models in the full clemency model masks the more likely influence of political factors in states with executive models. To the extent that political factors play a role, they are more likely to do so in states that vest clemency authority in governors rather than administrative boards. ${ }^{254}$ To test this possibility, I re-ran the full model using only clemency decisions reached in states that vest sole clemency authority in the governor. This variant is better positioned than the general model to detect potential influence of political factors. Table 4 presents the results.

\footnotetext{
${ }^{253}$ Again, caution is especially warranted when drawing an inference from a negative finding. See supra note 157.

${ }^{244}$ See Victoria J. Palacios, Faith in Fantasy: The Supreme Court's Reliance on Commutation to Ensure Justice in Death Penalty Cases, 49 Vand. L. Rev. 311, 349, 362-63 (1996) (explaining that the foremost reason for the decline in grants of executive clemency is the political consequences to the executive).
} 
Table 4: Pure Executive Clemency Decision Model Results ${ }^{255}$

\begin{tabular}{|c|c|c|c|}
\hline & $\begin{array}{c}\text { Standard } \\
\text { Model }\end{array}$ & $\begin{array}{c}\text { Standard } \\
\text { Model Without } \\
\text { Prior Felony }\end{array}$ & $\begin{array}{c}\text { Standard } \\
\text { Model for } \\
\text { Post-1984 } \\
\text { Cases }\end{array}$ \\
\hline \multicolumn{4}{|l|}{ Defendant: } \\
\hline AFRICAN-AMERICAN & $.43(.65)$ & $.43(.65)$ & $.16(.73)$ \\
\hline HISPANIC & $.49(1.97)$ & $.58(2.04)$ & $-4.67(66.15)$ \\
\hline OTHER & $4.55 *(1.90)$ & $4.61 *(1.89)$ & $13.39(61.44)$ \\
\hline FEMALE & $-7.52(34.00)$ & $-7.60(34.00)$ & $-11.36(195.28)$ \\
\hline $\mathrm{AGE}$ & $-.06(.04)$ & $-.06(.04)$ & $-.02(.05)$ \\
\hline EDUCATION & $-.45 *(.19)$ & $-.44 *(.19)$ & $-.46 *(.21)$ \\
\hline MARRIED & $-.43(.79)$ & $-.42(.79)$ & $-.65(.90)$ \\
\hline PRIOR FELONY & $-.35(.70)$ & - & $1.08(1.14)$ \\
\hline \multicolumn{4}{|l|}{ Political: } \\
\hline PRESIDENT ELEC YeAR & $-.14(1.01)$ & $-.09(1.01)$ & $.64(1.21)$ \\
\hline GOVERNOR ELEC YEAR & $-.07(.91)$ & $-.06(.91)$ & $-.46(1.16)$ \\
\hline ELECTED STATE JUDGES & $.25(1.12)$ & $.25(1.13)$ & $.44(1.44)$ \\
\hline DEMOCRATIC GOV & $-.55(.97)$ & $-.55(.97)$ & $.05(1.24)$ \\
\hline CATHOLIC GOV & $.40(1.89)$ & $.25(1.87)$ & $-11.22(102.68)$ \\
\hline FEMALE Gov & - & - & - \\
\hline GOVERNOR'S AGE & $-.05(.05)$ & $-.06(.04)$ & $-.02(.08)$ \\
\hline LAWYER GOV & $-.66(1.33)$ & $-.62(1.33)$ & $.70(1.63)$ \\
\hline EXIT ClemenCy & $17.97(48.05)$ & $18.03(48.05)$ & $24.89(105.60)$ \\
\hline \multicolumn{4}{|l|}{ Structural: } \\
\hline POST-1984 & $-4.63 * *(1.01)$ & $-4.69 *(1.05)$ & 一 \\
\hline SOUTH & $-.96(1.59)$ & $-.99(1.56)$ & $6.62(50.68)$ \\
\hline constant & $12.36(3.95)^{* *}$ & $12.32(3.94)^{* *}$ & $-4.60(50.93)$ \\
\hline$\%$ predicted & 93.3 & 93.3 & 93.8 \\
\hline Pseudo $\mathrm{R}^{2}$ & .48 & .48 & .27 \\
\hline $\mathrm{N}$ (valid list.) & 193 & 193 & 160 \\
\hline
\end{tabular}

Note: $* \mathrm{p}<.05 ; * * \mathrm{p}<.01$

The first and most important observation is that even after focusing on only those states with a pure executive model-that is, those states most likely to facilitate political influence-not one political variable achieved statistical significance. Thus, not only did

${ }^{25 s}$ Table 4 reports regression coefficients and standard errors (in parentheses). A fourth, unreported run, involves the standard model for post-1984 without the PRIOR FELONY variable. Results from this alternative are generally consistent with the three reported runs. 
the expected political factors fail to achieve significance when all the cases were considered, but these factors remained nonsignificant even when I examined only clemency decisions made by governors. The general consistency of results from the full and executive-only models-presented in Tables 3 and 4, respectivelyforms a second important point: The influence of this study's factors on decisions made by governors did not substantially differ from the influence of those factors on decisions made either by administrative boards or by administrative boards in combination with governors. In general, the same defendant characteristics as well as structural variables emerged as statistically significant. ${ }^{256}$

\section{CONCLUSION}

Results from this study yield new insights into clemency decisions and the factors that influence them. Prior work dwells almost exclusively on defendant characteristics and is largely confirmed by results from this broader study. By examining political and structural variables, along with a cluster of defendant background variables, this study provides a more complex and complete picture of clemency decision determinants.

My findings confirm the theoretical prediction that the manner in which states structure clemency decisionmaking authority influences clemency decisions. In addition, this study also confirms the clemency system's systematic bias in favor of women. My findings confound predictions about the salience of race and ethnicity on

${ }^{2{ }^{26}}$ Although a focus on clemency decisions reached only in states with a pure executive model generated findings generally consistent with the entire universe of clemency decisions (Table 3), some minor changes emerged. For example, when governors alone decided clemency, the importance of a defendant's gender and age diminished, though the influence of "other race" became statistically significant. In the structural variable cluster the only change was that of the South, which no longer exerted a statistically significant pull. In short, results for four of the twenty-one independent variables changed after the sample was reduced to include only clemency decisions made exclusively by governors. This modification reduced the sample size from 776 to 193 . Of the four results that changed, three variables that achieved statistical significance in the full model failed to do so in the pure executive model. Only one variableOTHER RACE-achieved significance in the supplemental run. To be sure, important differences distinguish different clemency models and these differences might help explain small changes. These small changes might also result from to a statistical artifact flowing from the reduction of the already small sample size by $75 \%$. Such a sample size reduction makes achieving statistical significance more difficult. 
clemency decisions, however. Another major surprise is the insignificance of political variables as determinants of clemency decisions. Perhaps odder still is that traditional political factors did not systematically influence clemency decisions, even though clearly some-perhaps many-individual politicians publicly behave as if they do.

The findings have a number of potential practical and policy implications. First, they underscore the importance of data, especially in a context where the stakes involve-quite literally-questions about who lives and dies. Arguments that decisions involving clemency in particular and the death penalty in general are arbitrary or inconsistently distributed would benefit from closer attention to data. Too often, anecdotes distort public and academic debates. ${ }^{257}$ An empirical look at these issues reveals that some common assumptions about clemency are correct, but others are either incorrect, misleading, or both. In this regard, the fact that political factors did not emerge as significant is especially important given the rhetoric that typically accompanies debates about clemency in particular and the death penalty more generally. The combination of the results in Tables 3 and, in particular, Table 4 suggests that critiques advanced against the use of clemency should focus on nonpolitical factors as reasons for the inconsistent application of clemency.

Second, debates about clemency are inexorably linked to larger debates surrounding the death penalty. Results from this study, while mixed, on balance fit within the larger critique that the death penalty is inconsistently and arbitrarily applied. Although traditional criticisms that the death penalty's application is distorted by race, ethnicity, and political factors are not available in the clemency context, clemency critics can point to the problematic influences of gender as well as the happenstance of structure as destabilizing clemency decisions. The argument that because clemency is, by design, an extrajudicial check on the criminal justice system and, as such, need not concern itself with principles such as consistency and evenhandedness should not make us turn a blind eye to sys-

${ }^{257}$ For a discussion of the power of anecdotal evidence in legal policy, see David A. Hyman, Lies, Damned Lies, and Narrative, 73 Ind. L.J. 797 (1998) (illustrating how anecdotes distort health care policy development). 
tematic bias. Indeed, it is because clemency is often the final check separating life and death that such principles are at a premium. ${ }^{25 s}$

Third, the results have implications for the future of clemency. The relative importance of clemency within the death penalty context has diminished significantly over time. This diminishment flows from the interaction of two trends: At the same time the number of death sentences and executions has increased, the number of clemency grants has decreased. For example, after 1984, the ratio of successful clemency petitions to executions dropped dramatically. Before 1985, the number of successful clemency petitions was slightly more than three times greater than the number of executions (105 to 32). After 1984, however, the ratio reversed: The number of executions (566) was seven times larger than the number of removals through clemency (73). The diminished number of clemency grants is not without important consequences, such as the implications for the possibility of judicial error. Even as successful clemency petitions from death row inmates become increasingly rare, however, the arbitrary and uneven dispensation of the relatively dwindling number of clemency grants endures as problem. $^{259}$

Of course, my assertion that a problem flows from a steady diminution of successful clemency grants begs one important question: Does the dwindling number of successful clemency petitions reflect an ever-decreasing number of worthy clemency candidates or, rather, evolving perceptions about the appropriate use of clemency? Indeed, other actors in the death penalty process-notably, prosecutors, jurors, and judges-might effectively be performing some (but not all) of the functions that clemency is designed to perform when they consider aggravating and mitigating circumstances surrounding capital cases. ${ }^{260}$ Admittedly, a satisfactory response to this question eludes. Although it remains far from clear

${ }^{2 s}$ The Supreme Court has hinted at possible due process boundaries demarking the outer limits of discretion. See supra note 15 and accompanying text.

${ }^{259}$ See id.

${ }^{2 \times}$ See, e.g., Payne v. Tennessee, 501 U.S. 808, 827 (1991) (noting that the Eighth Amendment does not erect a per se bar excluding victim impact evidence from capital sentencing juries); Zant v. Stevens, 462 U.S. 862, 878 (1983) (discussing the role of aggravating factors in capital sentencing); Lockett v. Ohio, 438 U.S. 586, 608 (1978) (concluding that the state may not preclude consideration of relevant mitigating factors in capital sentencing). 
what the optimal rate of clemency grants might be, the dramatic change in the clemency-to-execution ratio before and after 1984 at the very least suggests that concern over how clemency now functions is not misplaced. This concern rests partly on the reasonableness of the assumption that prosecutors, jurors, and judges have performed generally consistently during the past few decades. If so, and if death row inmates' general culpability has not changed dramatically over time, we must look elsewhere to explain the dramatic decline in the use of clemency.

Interesting questions-ones not addressed by existing dataendure and would benefit from future scholarly attention. Because the BJS dataset does not reveal a prisoner's identity, efforts to match these data with other, defendant-specific data are problematic. For example, information on the race of the defendant's victim is unknown, as well as its possible influence on clemency decisions. ${ }^{261}$ It would also be helpful to know whether the capital murders took place incident to domestic violence. In addition, although this study assumes no variation in the quality of clemency petitions, information on the petitions' nature and quality as well as the defendants' legal representation would also assist future work. Finally, whether the administration of clemency in the death penalty context is similar to other contexts deserves careful study.

States committed to the death penalty must take clemency seriously. This requires an accurate understanding of how clemency operates and how it is distributed. Quality data and empirical analyses contribute-and, indeed, are essential-to our understanding of clemency, especially its role in the death penalty context. Results from this study uncover critical misperceptions and reveal disquieting influences on clemency decisions. Clemency's unique and critical functions and its life and death consequence require that its application be clear, evenhanded, and transparent.

\footnotetext{
${ }^{261}$ Recall that prior research has found that the race of a defendant's victim is a significant determinant in whether a defendant is prosecuted for a capital murder and receives the death penalty. See supra notes 148-52 and accompanying text.
} 